\title{
LEVEL II SCOUR ANALYSIS FOR BRIDGE 3 (EASTTH00010003) on TOWN HIGHWAY 1, crossing the EAST BRANCH PASSUMPSIC RIVER, EAST HAVEN, VERMONT
}

Open-File Report 97-759

Prepared in cooperation with

VERMONT AGENCY OF TRANSPORTATION

and

FEDERAL HIGHWAY ADMINISTRATION

U.S. Department of the Interior

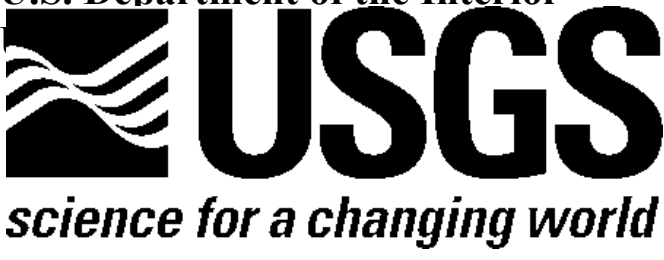




\section{LEVEL II SCOUR ANALYSIS FOR BRIDGE 3 (EASTTH00010003) on TOWN HIGHWAY 1, crossing the EAST BRANCH PASSUMPSIC RIVER, EAST HAVEN, VERMONT}

By RONDA L. BURNS and ERICK M. BOEHMLER

U.S. Geological Survey Open-File Report 97-759

Prepared in cooperation with

VERMONT AGENCY OF TRANSPORTATION and

FEDERAL HIGHWAY ADMINISTRATION 


\title{
U.S. DEPARTMENT OF THE INTERIOR BRUCE BABBITT, Secretary
}

\author{
U.S. GEOLOGICAL SURVEY \\ Mark Schaefer, Acting Director
}

For additional information write to:

District Chief

U.S. Geological Survey 361 Commerce Way

Pembroke, NH 03275-3718
Copies of this report may be purchased from:

U.S. Geological Survey

Branch of Information Services

Open-File Reports Unit

Box 25286

Denver, CO 80225-0286 


\section{CONTENTS}

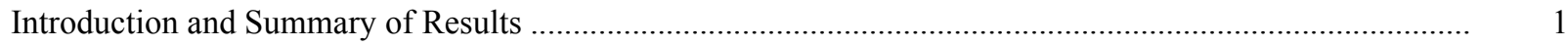

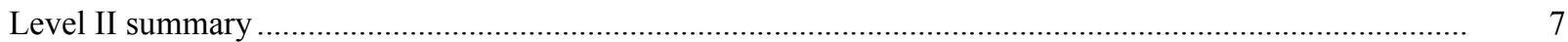

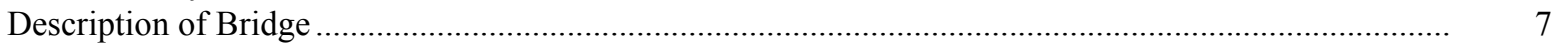

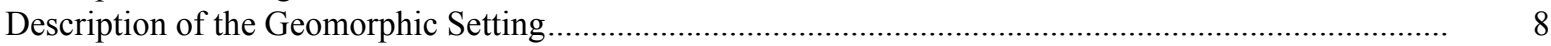

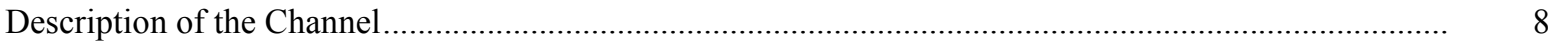

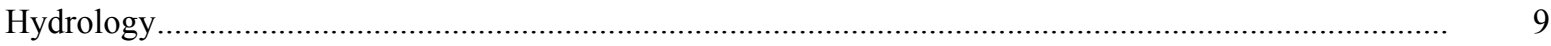

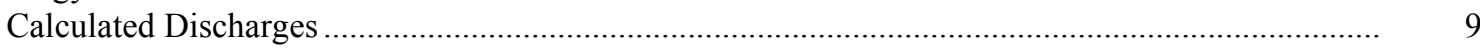

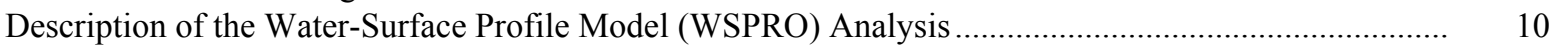

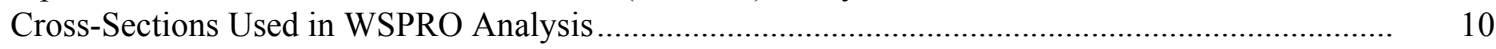

Data and Assumptions Used in WSPRO Model ...................................................................... 11

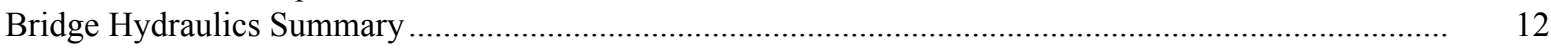

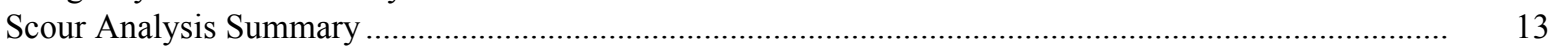

Special Conditions or Assumptions Made in Scour Analysis ...................................................... 13

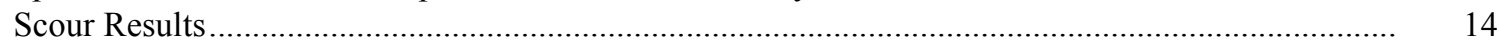

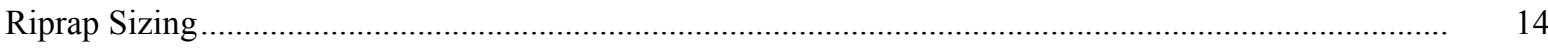

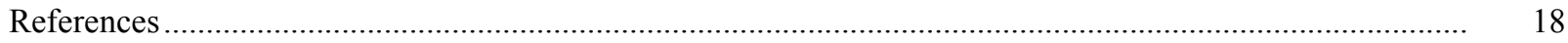

Appendixes:

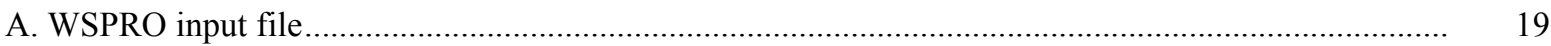

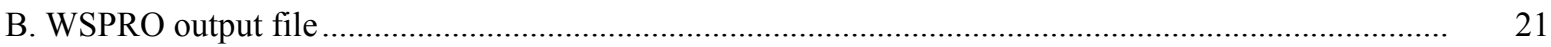

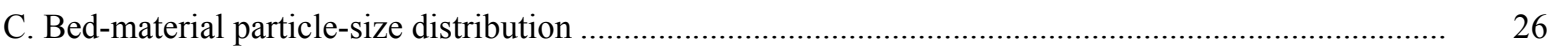

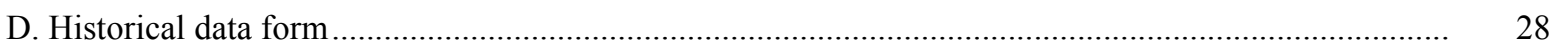

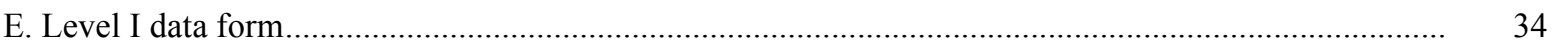

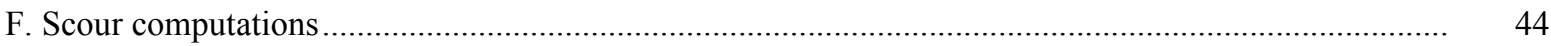

\section{FIGURES}

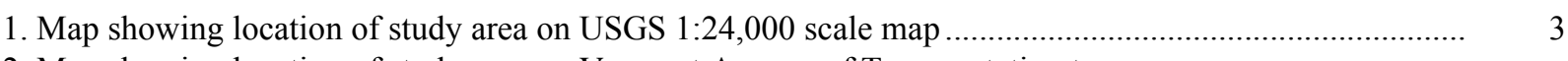

2. Map showing location of study area on Vermont Agency of Transportation town
highway map

3. Structure EASTTH00010003 viewed from upstream (August 14, 1995) ................................................ 5

4. Downstream channel viewed from structure EASTTH00010003 (August 14, 1995)............................ 5

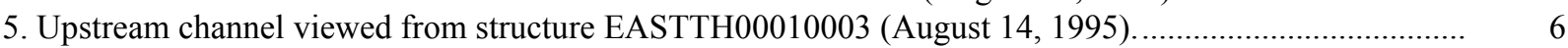

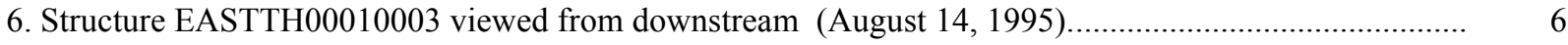

7. Water-surface profiles for the 100- and 500-year discharges at structure

EASTTH00010003 on Town Highway 1, crossing the East Branch Passumpsic River,

East Haven, Vermont.

8. Scour elevations for the 100- and 500-year discharges at structure

EASTTH00010003 on Town Highway 1, crossing the East Branch Passumpsic River,

East Haven, Vermont.

\section{TABLES}

1. Remaining footing/pile depth at abutments for the 100-year discharge at structure

EASTTH00010003 on Town Highway 1, crossing the East Branch Passumpsic River,

East Haven, Vermont

2. Remaining footing/pile depth at abutments for the 500-year discharge at structure

EASTTH00010003 on Town Highway 1, crossing the East Branch Passumpsic River,

East Haven, Vermont.

5




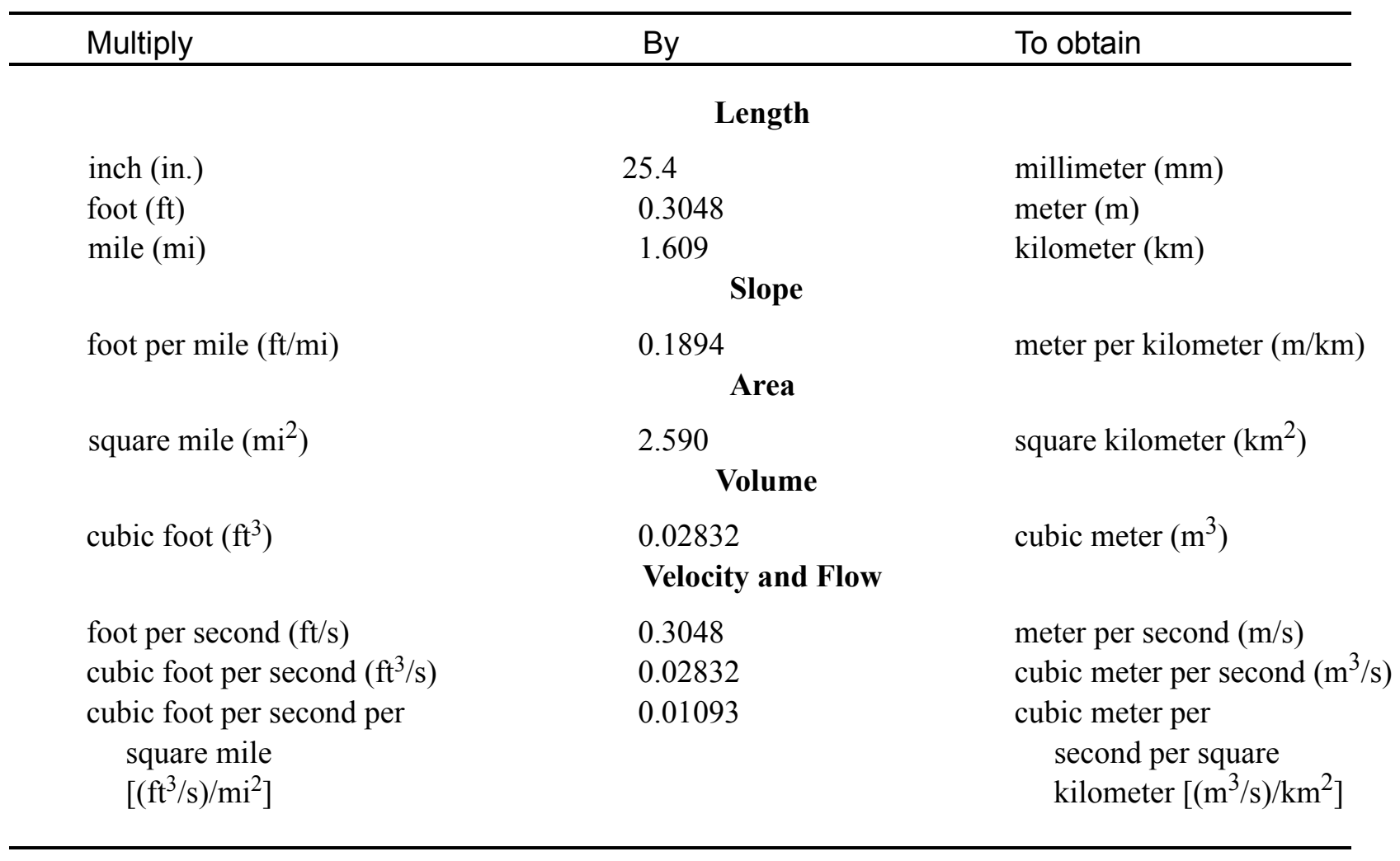

\section{OTHER ABBREVIATIONS}

$\begin{array}{lrlr}\mathrm{BF} & \text { bank full } & \text { LWW } & \text { left wingwall } \\ \mathrm{cfs} & \text { cubic feet per second } & \text { MC } & \text { main channel } \\ \mathrm{D}_{50} & \text { median diameter of bed material } & \text { RAB } & \text { right abutment } \\ \mathrm{DS} & \text { downstream } & \text { RABUT } & \text { face of right abutment } \\ \mathrm{elev} & \text { elevation } & \text { RB } & \text { right bank } \\ \mathrm{f} / \mathrm{p} & \text { flood plain } & \text { ROB } & \text { right overbank } \\ \mathrm{ft}^{2} & \text { square feet } & \text { RWW } & \text { right wingwall } \\ \mathrm{ft} / \mathrm{ft} & \text { feet per foot } & \text { TH } & \text { town highway } \\ \mathrm{JCT} & \text { junction } & \text { UB } & \text { under bridge } \\ \mathrm{LAB} & \text { left abutment } & \text { US } & \text { upstream } \\ \mathrm{LABUT} & \text { face of left abutment } & \text { USGS } & \text { United States Geological Survey } \\ \mathrm{LB} & \text { left bank } & \text { VTAOT Vermont Agency of Transportation } \\ \mathrm{LOB} & \text { left overbank } & \text { WSPRO } & \text { water-surface profile model }\end{array}$

In this report, the words "right" and "left" refer to directions that would be reported by an observer facing downstream. Sea level: In this report, "sea level" refers to the National Geodetic Vertical Datum of 1929-- a geodetic datum derived from a general adjustment of the first-order level nets of the United States and Canada, formerly called Sea Level Datum of 1929.

In the appendices, the above abbreviations may be combined. For example, USLB would represent upstream left bank. 


\title{
LEVEL II SCOUR ANALYSIS FOR BRIDGE 3 (EASTTH00010003) ON TOWN HIGHWAY 1, CROSSING THE EAST BRANCH PASSUMPSIC RIVER, EAST HAVEN, VERMONT
}

\author{
By Ronda L. Burns and Erick M. Boehmler
}

\section{INTRODUCTION AND SUMMARY OF RESULTS}

This report provides the results of a detailed Level II analysis of scour potential at structure EASTTH00010003 on Town Highway 1 crossing the East Branch Passumpsic River, East Haven, Vermont (figures 1-8). A Level II study is a basic engineering analysis of the site, including a quantitative analysis of stream stability and scour (U.S. Department of Transportation, 1993). Results of a Level I scour investigation also are included in Appendix E of this report. A Level I investigation provides a qualitative geomorphic characterization of the study site. Information on the bridge, gleaned from Vermont Agency of Transportation (VTAOT) files, was compiled prior to conducting Level I and Level II analyses and is found in Appendix D.

The site is in the White Mountain section of the New England physiographic province in northeastern Vermont. The 50.4- $\mathrm{mi}^{2}$ drainage area is in a predominantly rural and forested basin. In the vicinity of the study site, the surface cover on the left bank upstream is forest. On the remaining three banks the surface cover is pasture while the immediate banks have dense woody vegetation.

In the study area, the East Branch Passumpsic River has an incised, sinuous channel with a slope of approximately $0.003 \mathrm{ft} / \mathrm{ft}$, an average channel top width of $62 \mathrm{ft}$ and an average bank height of $5 \mathrm{ft}$. The channel bed material ranges from gravel to boulder with a median grain size $\left(\mathrm{D}_{50}\right)$ of $61.5 \mathrm{~mm}(0.187 \mathrm{ft})$. The geomorphic assessment at the time of the Level I and Level II site visit on August 14, 1995, indicated that the reach was stable.

The Town Highway 1 crossing of the East Branch Passumpsic River is a 89-ft-long, twolane bridge consisting of one 87-foot steel-beam span (Vermont Agency of Transportation, written communication, March 17, 1995). The opening length of the structure parallel to the bridge face is $84.7 \mathrm{ft}$. The bridge is supported by vertical, concrete abutments with sloped stone fill in front that creates a spill through embankment. The channel is skewed approximately zero degrees to the opening and the opening-skew-to-roadway is also zero degrees. 
Channel scour $0.5 \mathrm{ft}$ deeper than the mean thalweg depth was observed to the left of the center of the channel under the bridge during the Level I assessment. The scour countermeasures at the site are type- 2 stone fill (less than 36 inches diameter) along the downstream left bank and type-4 stone fill (less than 60 inches diameter) in front of the abutments creating spill through slopes. Additional details describing conditions at the site are included in the Level II Summary and Appendices D and E.

Scour depths and recommended rock rip-rap sizes were computed using the general guidelines described in Hydraulic Engineering Circular 18 (Richardson and others, 1995) for the 100- and 500-year discharges. Total scour at a highway crossing is comprised of three components: 1) long-term streambed degradation; 2) contraction scour (due to accelerated flow caused by a reduction in flow area at a bridge) and; 3 ) local scour (caused by accelerated flow around piers and abutments). Total scour is the sum of the three components. Equations are available to compute depths for contraction and local scour and a summary of the results of these computations follows.

Contraction scour for all modelled flows ranged from 0 to $1.8 \mathrm{ft}$. The worst-case contraction scour occurred at the 500-year discharge. Abutment scour ranged from 6.4 to $11.7 \mathrm{ft}$. The worst-case abutment scour occurred at the 500-year discharge. Additional information on scour depths and depths to armoring are included in the section titled "Scour Results". Scoured-streambed elevations, based on the calculated scour depths, are presented in tables 1 and 2. A cross-section of the scour computed at the bridge is presented in figure 8. Scour depths were calculated assuming an infinite depth of erosive material and a homogeneous particle-size distribution.

It is generally accepted that the Froehlich equation (abutment scour) gives "excessively conservative estimates of scour depths" (Richardson and others, 1995, p. 47). Usually, computed scour depths are evaluated in combination with other information including (but not limited to) historical performance during flood events, the geomorphic stability assessment, existing scour protection measures, and the results of the hydraulic analyses. Therefore, scour depths adopted by VTAOT may differ from the computed values documented herein. 


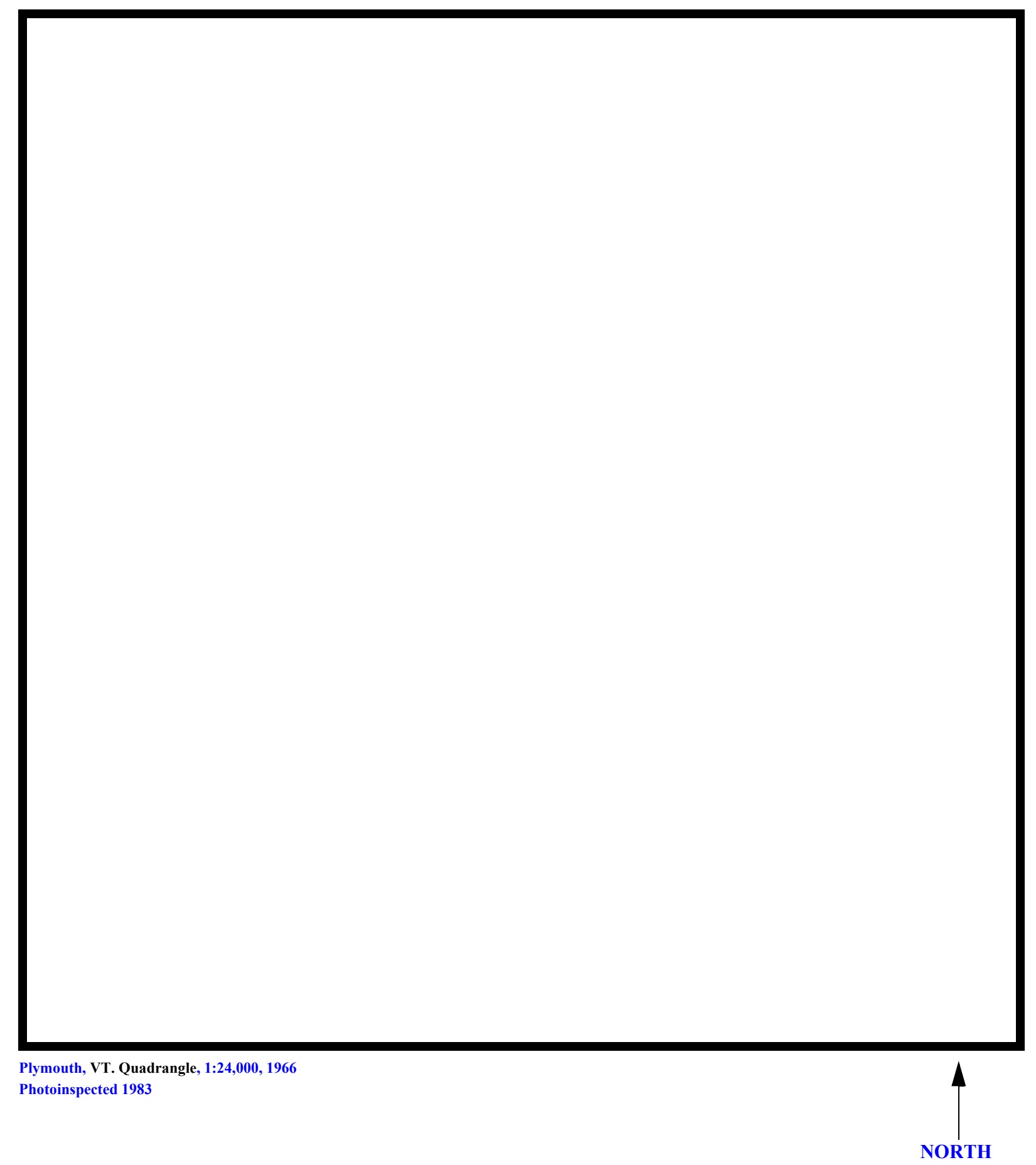

Figure 1. Location of study area on USGS 1:24,000 scale map. 
Figure 2. Location of study area on Vermont Agency of Transportation town highway map. 

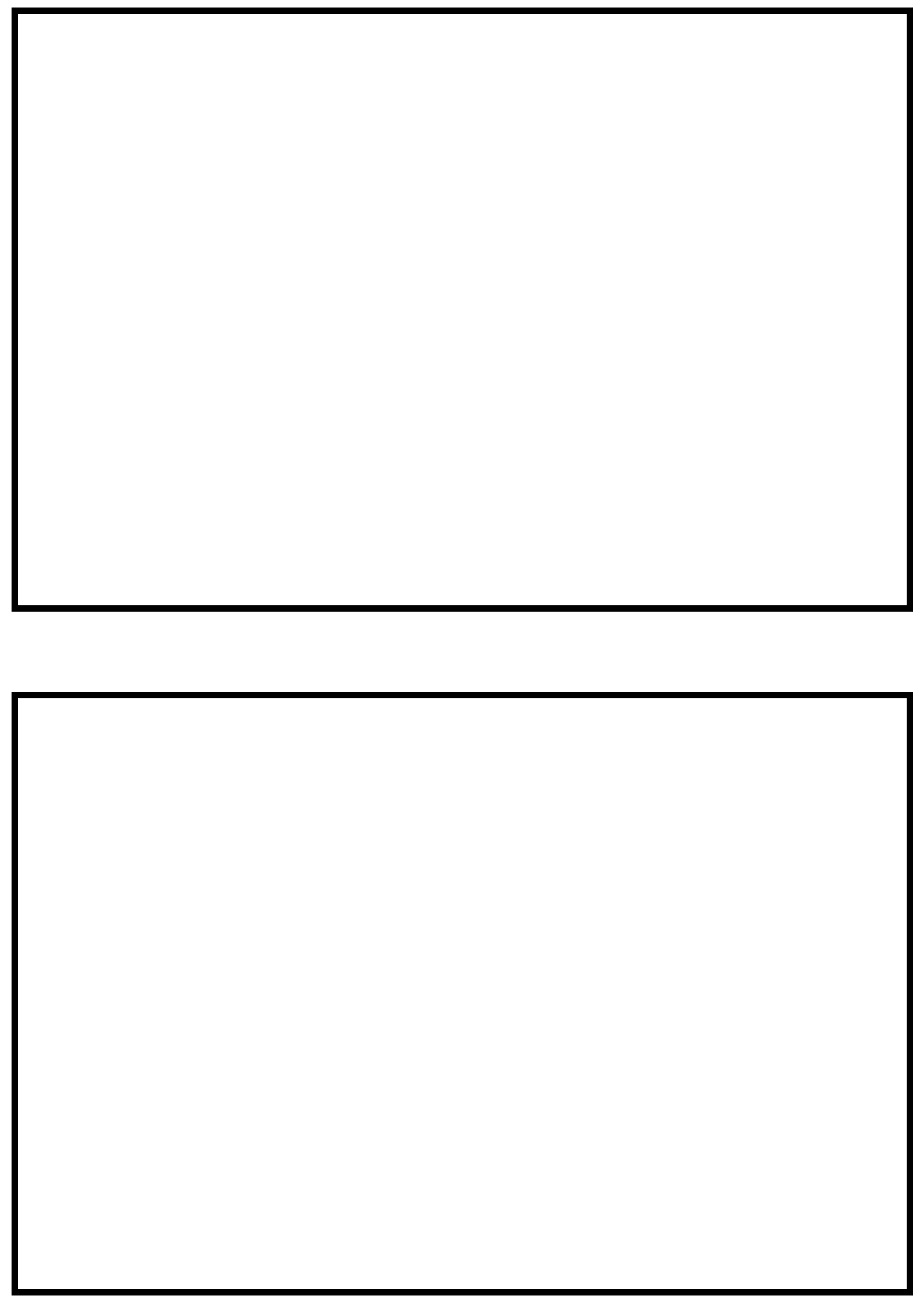

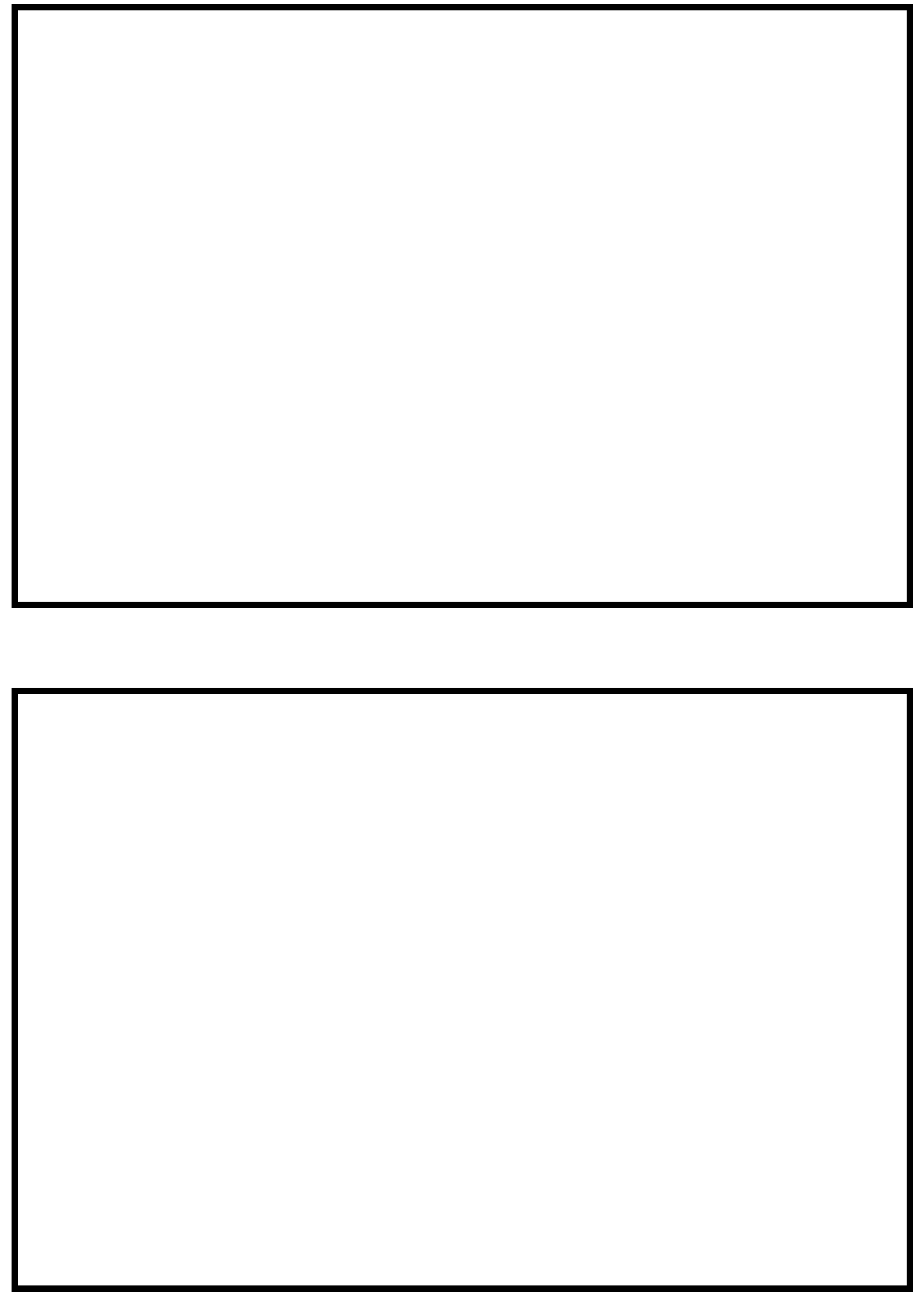


\section{LEVEL II SUMMARY}

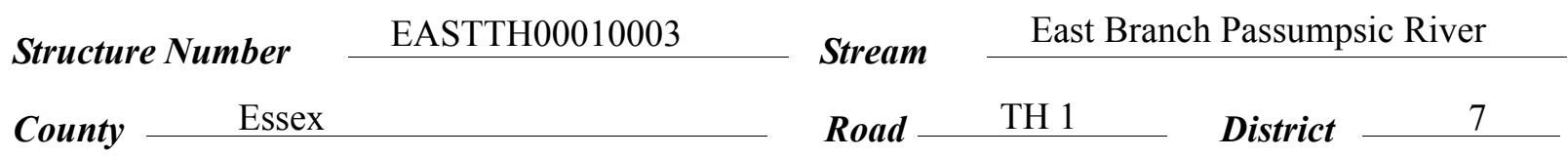

\section{Description of Bridge}

\begin{tabular}{|c|c|c|c|c|}
\hline & \multirow{2}{*}{ Bridge width } & \multirow{2}{*}{$\begin{array}{l}f t \\
\text { Straigh }\end{array}$} & \multirow[b]{2}{*}{$\begin{array}{l}\text { Max span length } \\
\text { it }\end{array}$} & 87 \\
\hline \multirow{2}{*}{\multicolumn{3}{|c|}{$\begin{array}{c}\text { Alignment of bridge to road (on curve or straight) } \\
\text { Vertical, concrete }\end{array}$}} & & \\
\hline & & \multirow{2}{*}{ Embankment type } & Sloping & \\
\hline Abutment type & Yes & & $8 / 14 / 95$ & \\
\hline \multirow{2}{*}{$\begin{array}{l}\text { Stone fill on abutment? } \\
\text { Dnanimtin... } \\
\text { slopes. }\end{array}$} & Type- 4 , in front of & $\begin{array}{l}\text { Drto of incnortion } \\
\text { the left and right abu }\end{array}$ & atments creating spi & llthrough \\
\hline & & & & \\
\hline
\end{tabular}

Abutments are concrete with stone fill spillthrough

slopes in front. Channel scour $0.5 \mathrm{ft}$ deep is under the bridge to the left of the center of the channel.

No

Is bridge skewed to flood flow according to Yes 'survey? Angle

There is a mild channel bend in the upstream reach.

Debris accumulation on bridge at time of Level I or Level II site visit:

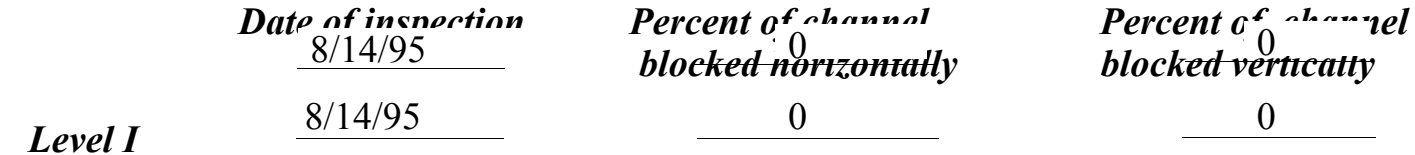

Level II

Moderate. There is an abundance of trees along the banks and the stream is sinuous.

Potential for debris

None as of 8/14/95.

Doscriho any, foaturos noar ar at tho hridos that mav, affoct flou, (includo ahsorvation dato) 


\section{Description of the Geomorphic Setting}

General topography The channel is located within a moderate relief valley with a narrow flood plain.

Geomorphic conditions at bridge site: downstream (DS), upstream (US)

Date of inspection $\quad 8 / 14 / 95$

DS left: $\quad$ Steep channel bank

DS right: $\quad$ Narrow flood plain

US left: $\quad$ Steep channel bank

US right: $\quad$ Narrow flood plain

\section{Description of the Channel}

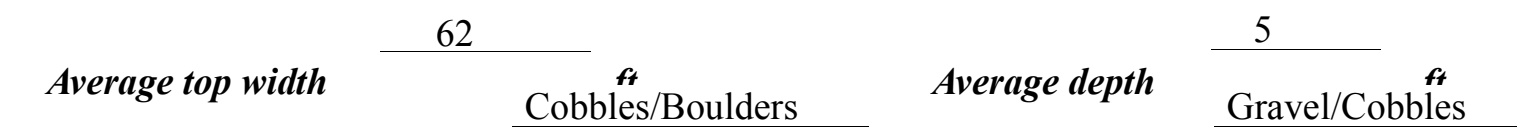

Predominant bed material Bank material Sinuous but stable

with semi-allúvial channel boundaries and a narrow flood plain.

$8 / 14 / 95$

Vegetative co 1 Trees and brush with grass on the overbank

DS left: $\quad$ Trees and brush with grass on the overbank

DS right: Trees

US left: $\quad$ Trees and brush with grass on the overbank

US right: $\quad$ Yes

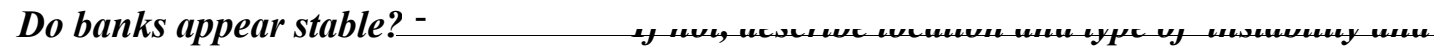

date of observation.

None as of $8 / 14 / 95$.

Describe any obstructions in channel and date of observation. 


\title{
Hydrology
}

Drainage area $\quad 50.4 \mathrm{mi}^{2}$

Percentage of drainage area in physiographic provinces: (approximate)

Physiographic province/section

New England/White Mountain
Percent of drainage area 100

\begin{abstract}
Is drainage area considered rural or urban?
Rural None. urbanization:

Describe any significant
\end{abstract}

Yes

Is there a USGS gage on the stream of interost? East Branch Passumpsic near East Haven, VT USGS gage description 01133000

USGS gage number

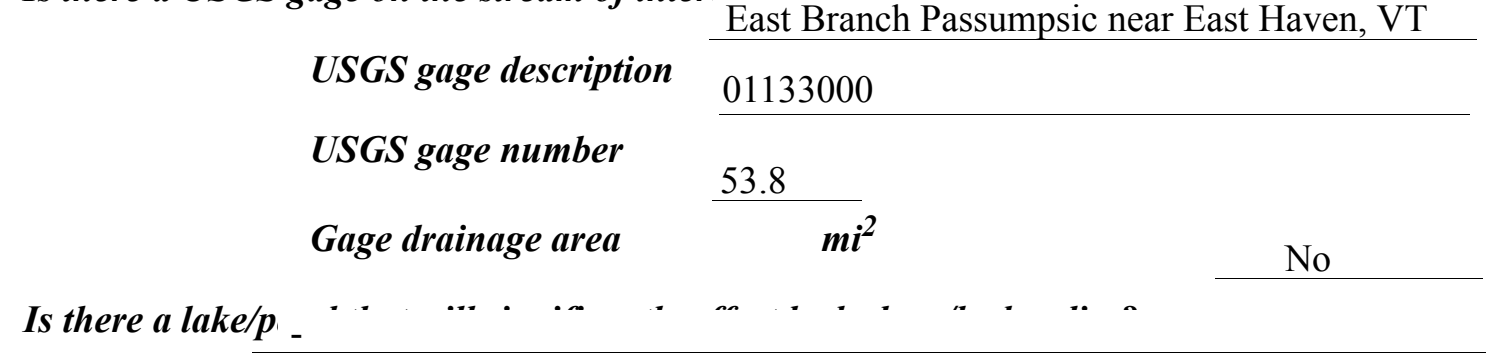

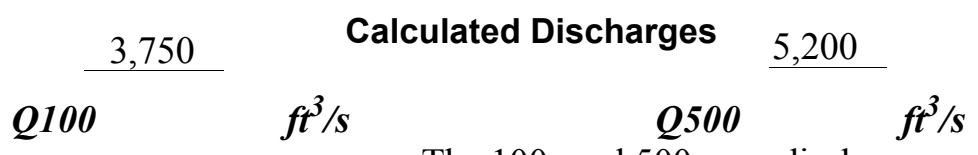

The 100- and 500-year discharges are based on a

drainage area relationship [(50.4/53.8)exp 0.67] with gage number 01133000 near East Haven.

The 100- and 500- year discharges at the gage were developed using a log-Pearson type-III analysis of annual peak-flow data (Interagency Advisory Committee on Water Data, 1982). The values used were within a range defined by flood frequency curves developed from several empirical methods (Benson, 1962; Johnson and Tasker, 1974; FHWA, 1983; Potter, 1957a\&b; Talbot, 1887). 


\section{Description of the Water-Surface Profile Model (WSPRO) Analysis}

Datum for WSPRO analysis (USGS survey, sea level, VTAOT plans) ～USGS survey

Datum tie between USGS survey and VTAOT plans $\quad$ Add 0.28 to the VT AOT plans to

obtain the USGS arbitrary survey datum.

Description of reference marks used to determine USGS datum. $\quad$ RM1 is a chiseled X on top of the concrete guard rail post on the downstream left bank (elev. $979.38 \mathrm{ft}$, arbitrary survey datum). RM2 is a chiseled $\mathrm{X}$ on top of the concrete guard rail post on the upstream right bank (elev. $979.10 \mathrm{ft}$, arbitrary survey datum). RM3 is a metal disc stamped "VT Highway

Department Benchmark" on the concrete guard rail post on the downstream right bank (elev. $979.66 \mathrm{ft}$, arbitrary survey datum).

\begin{tabular}{|c|c|c|c|}
\hline${ }^{1}$ Cross-section & $\begin{array}{c}\text { Section } \\
\text { Reference } \\
\text { Distance } \\
\text { (SRD) in feet }\end{array}$ & $\begin{array}{c}{ }^{2} \text { Cross-section } \\
\text { development }\end{array}$ & Comments \\
\hline EXITX & -66 & 1 & Exit section \\
\hline FULLV & 0 & 2 & $\begin{array}{l}\text { Downstream Full-valley } \\
\text { section (Templated from } \\
\text { EXITX) }\end{array}$ \\
\hline BRIDG & 0 & 1 & Bridge section \\
\hline RDWAY & 15 & 1 & Road Grade section \\
\hline APTEM & 109 & 1 & $\begin{array}{l}\text { Approach section as sur- } \\
\text { veyed (Used as a tem- } \\
\text { plate) }\end{array}$ \\
\hline APPRO & 114 & 2 & $\begin{array}{l}\text { Modelled Approach sec- } \\
\text { tion (Templated from } \\
\text { APTEM) }\end{array}$ \\
\hline
\end{tabular}

${ }^{1}$ For location of cross-sections see plan-view sketch included with Level I field form, Appendix E. For more detail on how cross-sections were developed see WSPRO input file.

2 Cross-section development: (1) survey at SRD, (2) shift of survey data to SRD, (3) modification of survey data, (4) composite bridge section, (5) other. 


\section{Data and Assumptions Used in WSPRO Model}

Hydraulic analyses of the reach were done by use of the Federal Highway Administration's WSPRO step-backwater computer program (Shearman and others, 1986, and Shearman, 1990). The analyses reported herein reflect conditions existing at the site at the time of the study. Furthermore, in the development of the model it was necessary to assume no accumulation of debris or ice at the site. Results of the hydraulic model are presented in the Bridge Hydraulic Summary, Appendix B, and figure 7.

Channel roughness factors (Manning's " $n$ ") used in the hydraulic model were estimated using field inspections at each cross section following the general guidelines described by Arcement and Schneider (1989). Final adjustments to the values were made during the modelling of the reach. Channel " $\mathrm{n}$ " values for the reach ranged from 0.040 to 0.050 , and the overbank "n" value was 0.040 .

Normal depth at the exit section (EXITX) was assumed as the starting water surface. This depth was computed by use of the slope-conveyance method outlined in the user's manual for WSPRO (Shearman, 1990). The slope used was $0.0032 \mathrm{ft} / \mathrm{ft}$, which was estimated from the topographic map (U.S. Geological Survey, 1988).

The surveyed approach section (APTEM) was moved along the approach channel slope $(0.0084 \mathrm{ft} / \mathrm{ft})$ to establish the modelled approach section (APPRO), one bridge length upstream of the upstream face as recommended by Shearman and others (1986). This location also provides a consistent method for determining scour variables. 


\section{Bridge Hydraulics Summary}

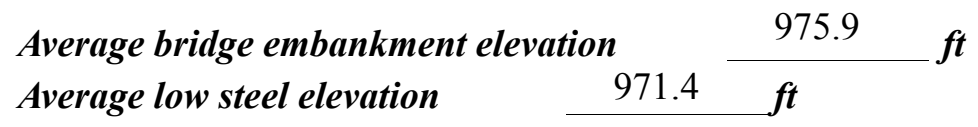

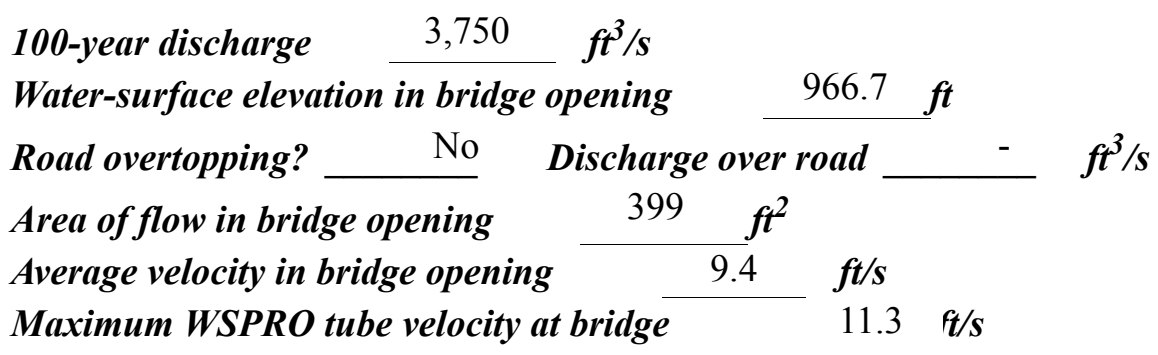

Water-surface elevation at Approach section with bridge Water-surface elevation at Approach section without bridge

Amount of backwater caused by bridge
968.7

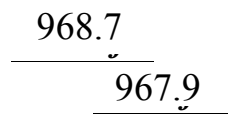

$0.8 \quad \boldsymbol{t}$

500-year discharge $\quad 5,200 \quad \mathrm{ft}^{3} / \mathrm{s}$

Water-surface elevation in bridge opening $966.8 f t$

Road overtopping? ___ No Discharge over road $f t^{3} / s$

Area of flow in bridge opening $\quad 405 \quad \mathrm{ft}^{2}$

Average velocity in bridge opening $12.8 \mathrm{ft} / \mathrm{s}$

Maximum WSPRO tube velocity at bridge 15.7 _s

Water-surface elevation at Approach section with bridge

Water-surface elevation at Approach section without bridge

Amount of backwater caused by bridge 2.4 .t

971.0

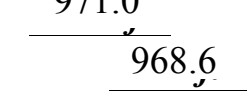

Incipient overtopping discharge __ _ $\quad \mathrm{ft}^{3} / \mathrm{s}$

Water-surface elevation in bridge opening $\quad-\quad t$

Area of flow in bridge opening $-\quad f t^{2}$

Average velocity in bridge opening

Maximum WSPRO tube velocity at bridge $f t / s$

$-\quad f t / s$

Water-surface elevation at Approach section with bridge Water-surface elevation at Approach section without bridge Amount of backwater caused by bridge $-\quad$ it

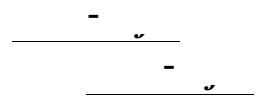




\section{Scour Analysis Summary}

\section{Special Conditions or Assumptions Made in Scour Analysis}

Scour depths were computed using the general guidelines described in Hydraulic Engineering Circular 18 (Richardson and others, 1995). Scour depths were calculated assuming an infinite depth of erosive material and a homogeneous particle-size distribution. The results of the scour analysis are presented in tables 1 and 2 and a graph of the scour depths is presented in figure 8 .

Contraction scour for the 100-year and 500-year discharges was computed by use of the Laursen clear-water contraction scour equation (Richardson and others, 1995, p. 32, equation 20). The computed streambed armoring depths suggest that armoring will not limit the depth of contraction scour.

Abutment scour for the left abutment was computed by use of the Froehlich equation (Richardson and others, 1995, p. 48, equation 28). Variables for the Froehlich equation include the Froude number of the flow approaching the embankments, the length of the embankment blocking flow, and the depth of flow approaching the embankment less any roadway overtopping.

Scour at the right abutment was computed by use of the HIRE equation (Richardson and others, 1995, p. 49, equation 29) because the HIRE equation is recommended when the length to depth ratio of the embankment blocking flow exceeds 25 . The variables used by the HIRE abutment-scour equation are defined the same as those defined for the Froehlich abutment-scour equation.

Because the influence of scour processes on the material of the spill-through embankments is uncertain, the scour depth at the vertical concrete abutment walls is unknown. Therefore, the total scour depth computed at the toe of the embankments was applied for the entire spill-through embankment as shown in figure 8 . 


\section{Scour Results}

100-yr discharge 500-yr discharge

Incipient

Contraction scour:

(Scour depths in feet)

Main channel

Live-bed scour

Clear-water scour

Depth to armoring

Left overbank

Right overbank

Local scour:

Abutment scour

Left abutment

6.4

8.2

6.9-

$11.7-$

Right abutment

Pier scour

Pier 1

Pier 2

Pier 3

Abutments:

Left abutment

Right abutment

Piers:

Pier 1

Pier 2

\section{Riprap Sizing}

overtopping

discharge

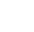




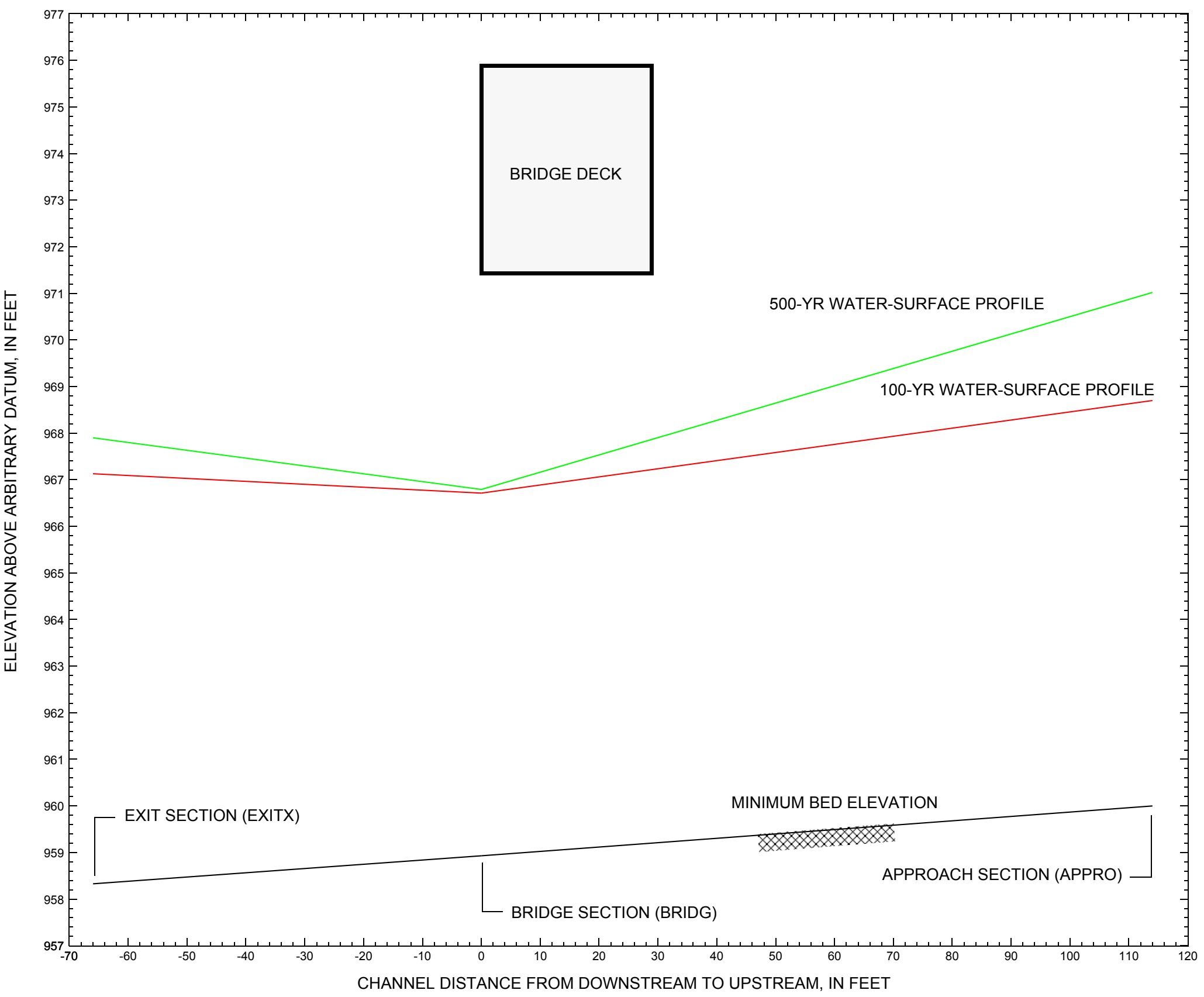

Figure 7. Water-surface profiles for the 100- and 500-yr discharges at structure EASTTH00010003 on Town Highway 1, crossing the East Branch Passumpsic River, East Haven, Vermont. 


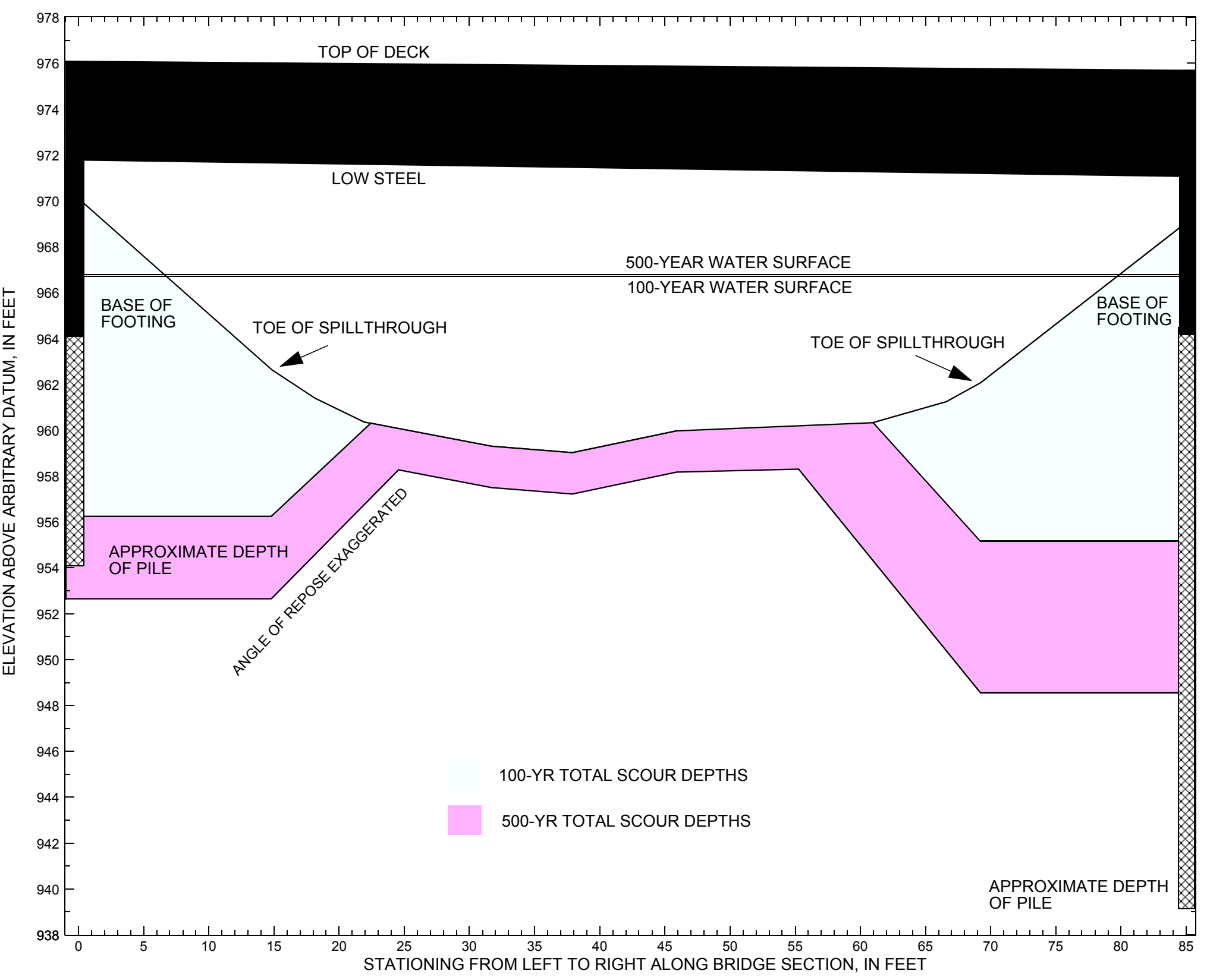

Figure 8. Scour elevations for the 100-yr and 500-yr discharges at structure EASTTH00010003 on Town Highway 1, crossing the East Branch Passumpsic River, East Haven, Vermont. 


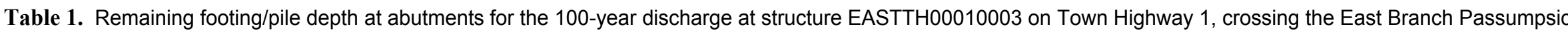
River, East Haven, Vermont.

[VTAOT, Vermont Agency of Transportation; --, no data]

\begin{tabular}{|c|c|c|c|c|c|c|c|c|c|c|c|}
\hline Description & Station $^{1}$ & $\begin{array}{l}\text { VTAOT } \\
\text { minimum } \\
\text { low-chord } \\
\text { elevation } \\
\text { (feet) }\end{array}$ & $\begin{array}{c}\text { Surveyed } \\
\text { minimum } \\
\text { low-chord } \\
\text { elevation } \\
\text { (feet) }\end{array}$ & $\begin{array}{c}\text { Bottom of } \\
\text { pile } \\
\text { elevation } \\
\text { (feet) }\end{array}$ & $\begin{array}{c}\text { Channel } \\
\text { elevation at } \\
\text { abutment/ } \\
\text { pier }^{2} \\
\text { (feet) }\end{array}$ & $\begin{array}{l}\text { Contraction } \\
\text { scour depth } \\
\text { (feet) }\end{array}$ & $\begin{array}{l}\text { Abutment } \\
\text { scour } \\
\text { depth } \\
\text { (feet) }\end{array}$ & $\begin{array}{l}\text { Pier } \\
\text { scour } \\
\text { depth } \\
\text { (feet) }\end{array}$ & $\begin{array}{l}\text { Depth of } \\
\text { total scour } \\
\text { (feet) }\end{array}$ & $\begin{array}{c}\text { Elevation of } \\
\text { scour }^{2} \\
\text { (feet) }\end{array}$ & $\begin{array}{c}\text { Remaining } \\
\text { footing/pile } \\
\text { depth } \\
\text { (feet) }\end{array}$ \\
\hline \multicolumn{12}{|c|}{100 -yr. discharge is 3,750 cubic-feet per second } \\
\hline Left abutment & 0.0 & 970.6 & 971.8 & 954.1 & -- & -- & -- & -- & -- & -- & 2.2 \\
\hline LABUT toe & 14.8 & -- & -- & -- & 962.7 & 0.0 & 6.4 & -- & 6.4 & 956.3 & -- \\
\hline RABUT toe & 69.2 & -- & -- & -- & 962.1 & 0.0 & 6.9 & -- & 6.9 & 955.2 & -- \\
\hline Right abutment & 84.7 & 970.3 & 971.1 & 939.2 & -- & -- & -- & -- & -- & -- & 16.0 \\
\hline
\end{tabular}

1.Measured along the face of the most constricting side of the bridge.

2.Arbitrary datum for this study.

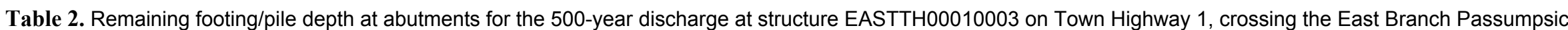
River, East Haven, Vermont.

[VTAOT, Vermont Agency of Transportation; --, no data]

\begin{tabular}{|c|c|c|c|c|c|c|c|c|c|c|c|}
\hline Description & Station $^{1}$ & $\begin{array}{l}\text { VTAOT } \\
\text { minimum } \\
\text { low-chord } \\
\text { elevation } \\
\text { (feet) }\end{array}$ & $\begin{array}{c}\text { Surveyed } \\
\text { minimum } \\
\text { low-chord } \\
\text { elevation } \\
\text { (feet) }\end{array}$ & $\begin{array}{c}\text { Bottom of } \\
\text { footing/pile } \\
\text { elevation }{ }^{2} \\
\text { (feet) }\end{array}$ & $\begin{array}{c}\text { Channel } \\
\text { elevation at } \\
\text { abutment/ } \\
\text { pier }^{2} \\
\text { (feet) }\end{array}$ & $\begin{array}{l}\text { Contraction } \\
\text { scour depth } \\
\text { (feet) }\end{array}$ & $\begin{array}{l}\text { Abutment } \\
\text { scour } \\
\text { depth } \\
\text { (feet) }\end{array}$ & $\begin{array}{l}\text { Pier } \\
\text { scour } \\
\text { depth } \\
\text { (feet) }\end{array}$ & $\begin{array}{l}\text { Depth of } \\
\text { total scour } \\
\text { (feet) }\end{array}$ & $\begin{array}{c}\text { Elevation of } \\
\text { scour }^{2} \\
\text { (feet) }\end{array}$ & $\begin{array}{c}\text { Remaining } \\
\text { footing/pile } \\
\text { depth } \\
\text { (feet) }\end{array}$ \\
\hline \multicolumn{12}{|c|}{500 -yr. discharge is 5,200 cubic-feet per second } \\
\hline Left abutment & 0.0 & 970.6 & 971.8 & 954.1 & -- & -- & -- & -- & -- & -- & -1.4 \\
\hline LABUT toe & 14.8 & -- & -- & -- & 962.7 & 1.8 & 8.2 & -- & 10.0 & 952.7 & -- \\
\hline RABUT toe & 69.2 & -- & -- & -- & 962.1 & 1.8 & 11.7 & -- & 13.5 & 948.6 & -- \\
\hline Right abutment & 84.7 & 970.3 & 971.1 & 939.2 & -- & -- & -- & -- & -- & -- & 9.4 \\
\hline
\end{tabular}

1.Measured along the face of the most constricting side of the bridge.

2.Arbitrary datum for this study. 


\section{SELECTED REFERENCES}

Arcement, G.J., Jr., and Schneider, V.R., 1989, Guide for selecting Manning's roughness coefficients for natural channels and flood plains: U.S. Geological Survey Water-Supply Paper 2339, 38 p.

Barnes, H.H., Jr., 1967, Roughness characteristics of natural channels: U.S. Geological Survey Water-Supply Paper 1849,213 p.

Benson, M. A., 1962, Factors Influencing the Occurrence of Floods in a Humid Region of Diverse Terrain: U.S. Geological Survey WaterSupply Paper 1580-B, 64 p.

Brown, S.A. and Clyde, E.S., 1989, Design of riprap revetment: Federal Highway Administration Hydraulic Engineering Circular No. 11, Publication FHWA-IP-89-016, 156 p.

Federal Highway Administration, 1983, Runoff estimates for small watersheds and development of sound design: Federal Highway Administration Report FHWA-RD-77-158.

Federal Highway Administration, 1993, Stream Stability and Scour at Highway Bridges: Participant Workbook: Federal Highway Administration Report FHWA-HI-91-011.

Froehlich, D.C., 1989, Local scour at bridge abutments in Ports, M.A., ed., Hydraulic Engineering--Proceedings of the 1989 National Conference on Hydraulic Engineering: New York, American Society of Civil Engineers, p. 13-18.

Hayes, D.C.,1993, Site selection and collection of bridge-scour data in Delaware, Maryland, and Virginia: U.S. Geological Survey WaterResources Investigation Report 93-4017, 23 p.

Interagency Advisory Committee on Water Data, 1982, Guidelines for determining flood flow frequency: U.S. Geological Survey, Bulletin 17B of the Hydrology Subcommittee, 190 p.

Johnson, C.G. and Tasker, G.D.,1974, Progress report on flood magnitude and frequency of Vermont streams: U.S. Geological Survey OpenFile Report 74-130, 37 p.

Lagasse, P.F., Schall, J.D., Johnson, F., Richardson, E.V., Chang, F., 1995, Stream Stability at Highway Structures: Federal Highway Administration Hydraulic Engineering Circular No. 20, Publication FHWA-IP-90-014, 144 p.

Laursen, E.M., 1960, Scour at bridge crossings: Journal of the Hydraulics Division, American Society of Civil Engineers, v. 86, no. HY2, p. 39-53.

Potter, W. D., 1957a, Peak rates of runoff in the Adirondack, White Mountains, and Maine woods area, Bureau of Public Roads

Potter, W. D., 1957b, Peak rates of runoff in the New England Hill and Lowland area, Bureau of Public Roads

Richardson, E.V. and Davis, S.R., 1995, Evaluating scour at bridges: Federal Highway Administration Hydraulic Engineering Circular No. 18, Publication FHWA-IP-90-017, 204 p.

Richardson, E.V., Simons, D.B., and Julien, P.Y., 1990, Highways in the river environment: Federal Highway Administration Publication FHWA-HI-90-016.

Ritter, D.F., 1984, Process Geomorphology: W.C. Brown Co., Debuque, Iowa, 603 p.

Shearman, J.O., 1990, User's manual for WSPRO--a computer model for water surface profile computations: Federal Highway Administration Publication FHWA-IP-89-027, 187 p.

Shearman, J.O., Kirby, W.H., Schneider, V.R., and Flippo, H.N., 1986, Bridge waterways analysis model; research report: Federal Highway Administration Publication FHWA-RD-86-108, 112 p.

Talbot, A.N., 1887, The determination of water-way for bridges and culverts.

U.S. Department of Transportation, 1993, Stream stability and scour at highway bridges, Participant Workbook: Federal Highway Administration Publication FHWA HI-91-011.

U.S. Geological Survey, 1988, West Burke, Vermont 7.5 Minute Series quadrangle map: U.S. Geological Survey Topographic Maps, Scale 1:24,000. 


\section{APPENDIX A: \\ WSPRO INPUT FILE}




\section{WSPRO INPUT FILE}

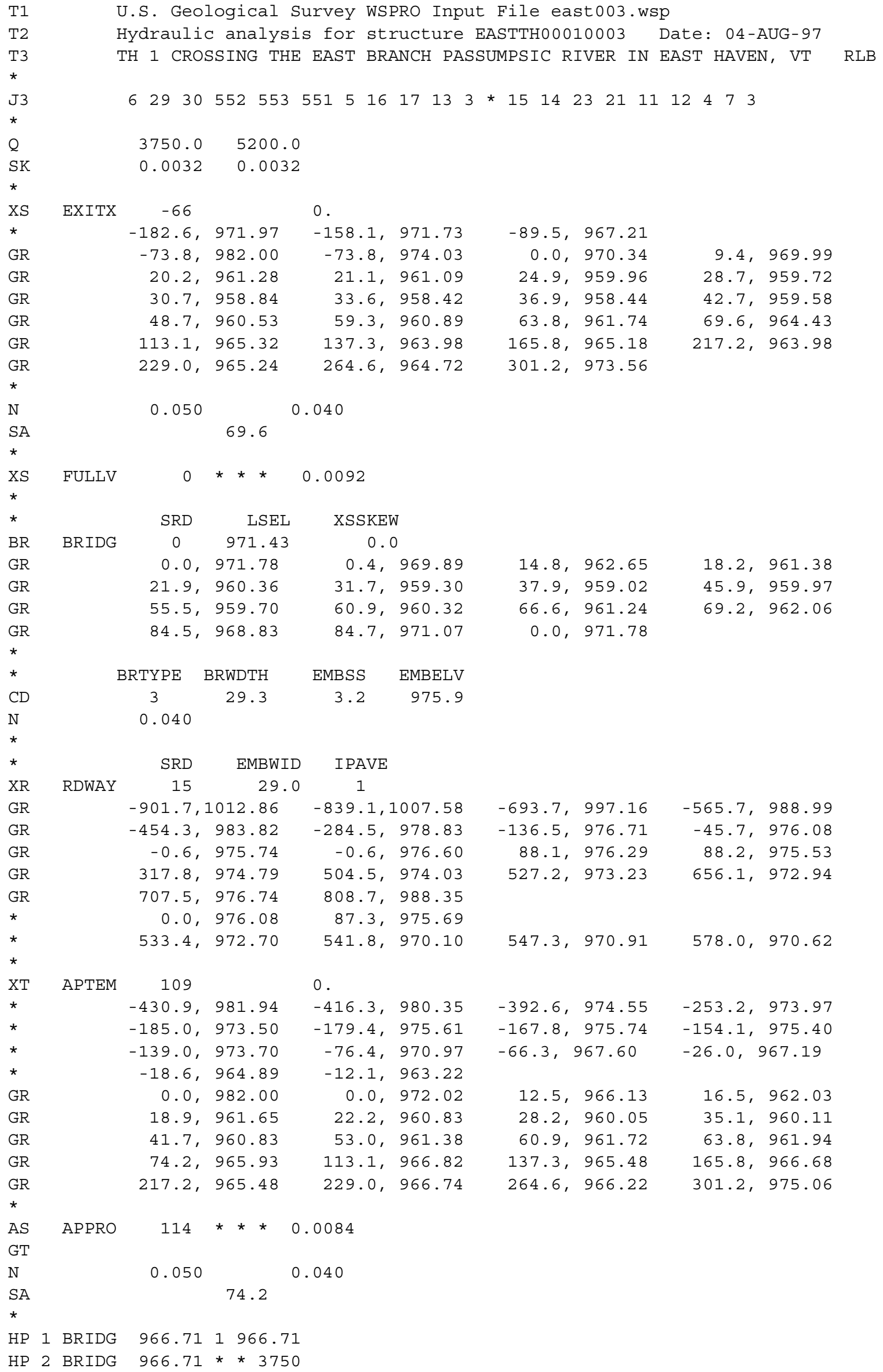




\section{APPENDIX B: \\ WSPRO OUTPUT FILE}




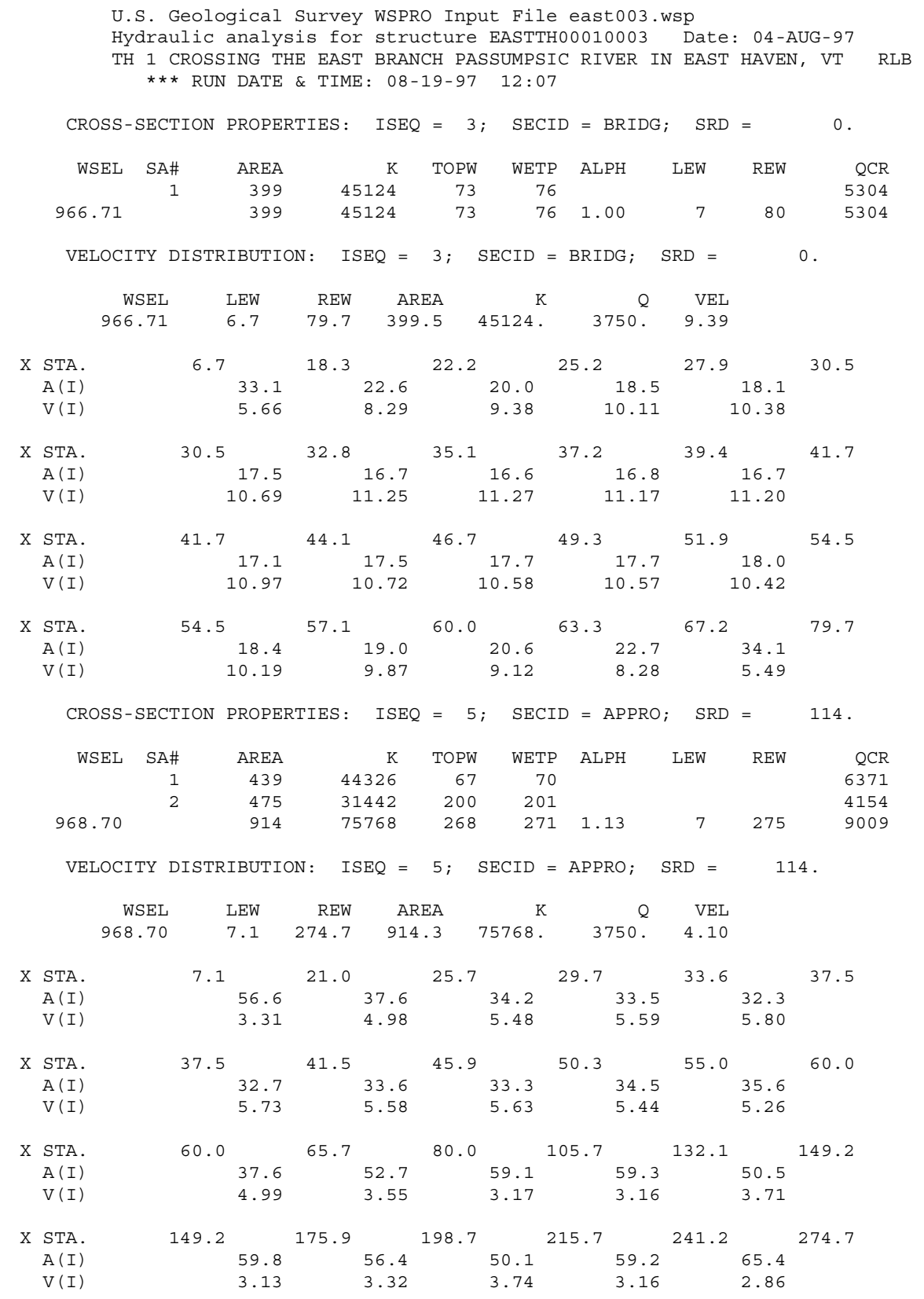


WSPRO OUTPUT FILE (continued)

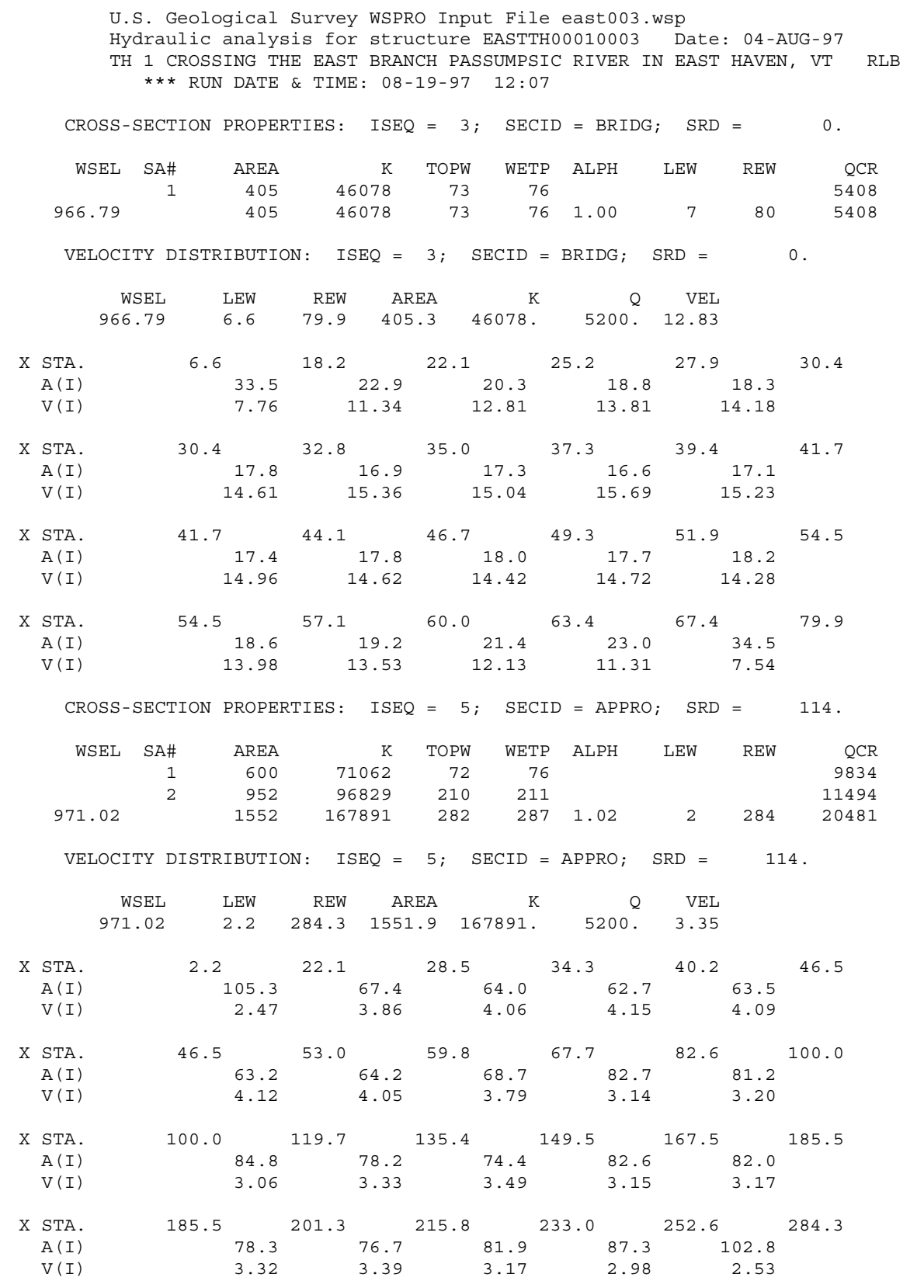


WSPRO OUTPUT FILE (continued)

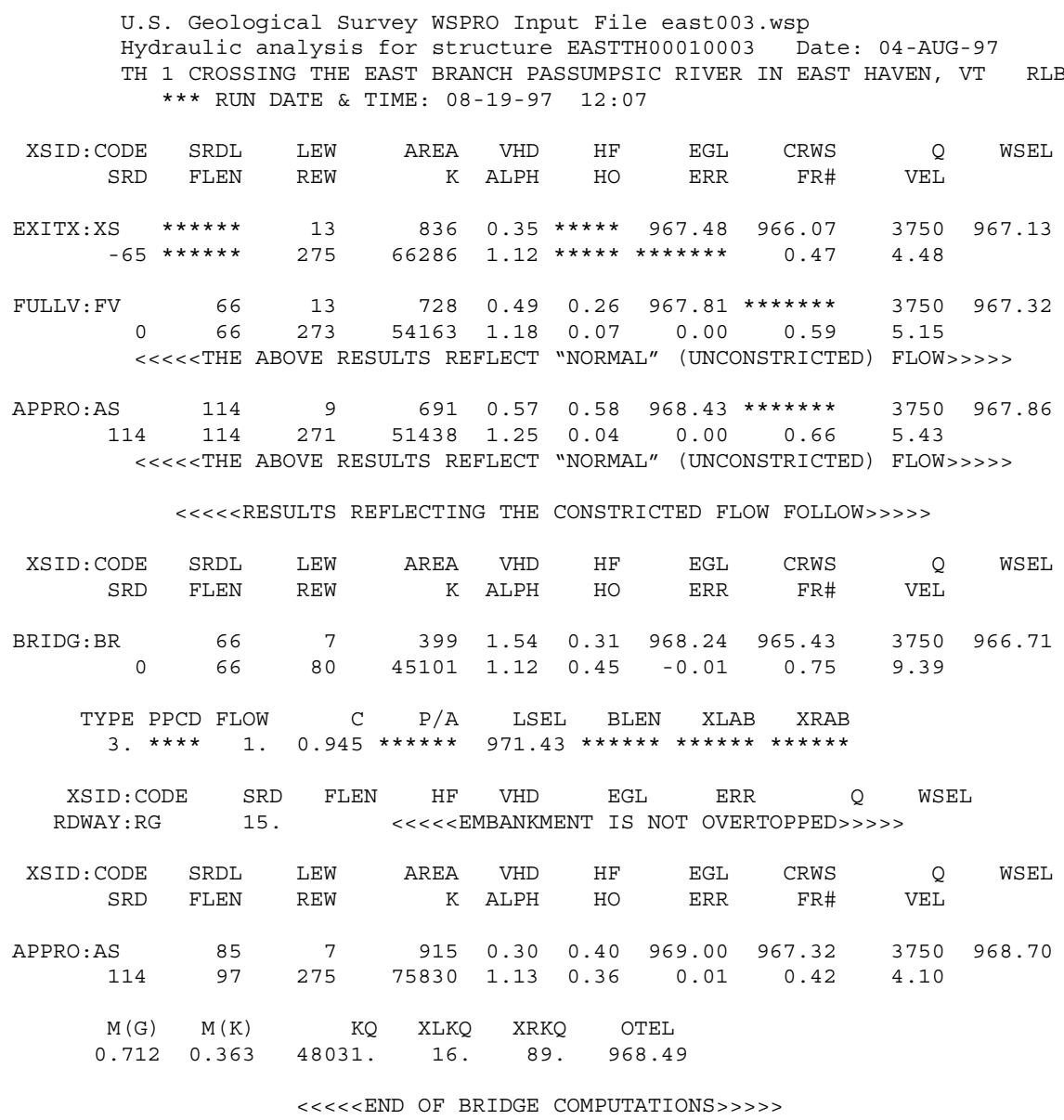

FIRST USER DEFINED TABLE.

\begin{tabular}{|c|c|c|c|c|c|c|c|c|}
\hline XSID : CODE & SRD & LEW & REW & Q & K & AREA & VEL & WSEL \\
\hline EXITX:XS & -66 & 13. & 275 . & 3750 . & 66286 & 836. & 4.48 & 967.13 \\
\hline FULLV : FV & 0 . & 13. & 273. & 3750. & 54163. & 728 & 5.15 & 967.32 \\
\hline BRIDG : BR & 0 . & 7. & 80. & 3750. & 45101. & 399. & 9.39 & 966.71 \\
\hline RDWAY : RG & \multicolumn{3}{|c|}{ 15. $* * \star * \star * * * * * * * \star * *$} & \multicolumn{3}{|c|}{$0 . * * * * * * * * * * * * * * * * * * *$} & \multicolumn{2}{|c|}{ 1. $00 * \star \star \star * \star * \star * *$} \\
\hline APPRO : AS & 114 & 7. & 275 . & 3750 . & 75830 & 915. & 4.10 & 968.70 \\
\hline XSID : CODE & XLKQ & XRKQ & & & & & & \\
\hline APPRO : AS & 16. & 89. & 48031 & & & & & \\
\hline
\end{tabular}

SECOND USER DEFINED TABLE.

\begin{tabular}{|c|c|c|c|c|c|c|c|c|c|}
\hline XSID : CODE & CRWS & FR\# & YMIN & YMAX & $\mathrm{HF}$ & $\mathrm{HO}$ & VHD & EGL & QL \\
\hline EXITX:XS & 966.07 & .47 & 958.42 & $982.00 *$ & $n$ & $* * *$ & 0.35 & 967.48 & 967.13 \\
\hline :FV & 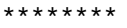 & 9 & 59.03 & 982.61 & 0.26 & 0.07 & 9 & .81 & 967.32 \\
\hline BRIDG : BR & 965.43 & .75 & 959.02 & 971.78 & 0.31 & 0.45 & 1.54 & 968.24 & 966.71 \\
\hline RDWAY : RG & $\star \star \star \star \star \star * \star * *$ & $\star \star \star * *$ & 972.94 & 012.86 & $* * * * *$ & *** & 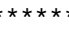 & $\star * *$ & 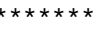 \\
\hline PPRO : AS & 967.32 & 0.42 & 960.09 & 982.04 & 0.40 & 0.36 & 0.30 & 969.00 & 968.70 \\
\hline
\end{tabular}


WSPRO OUTPUT FILE (continued)

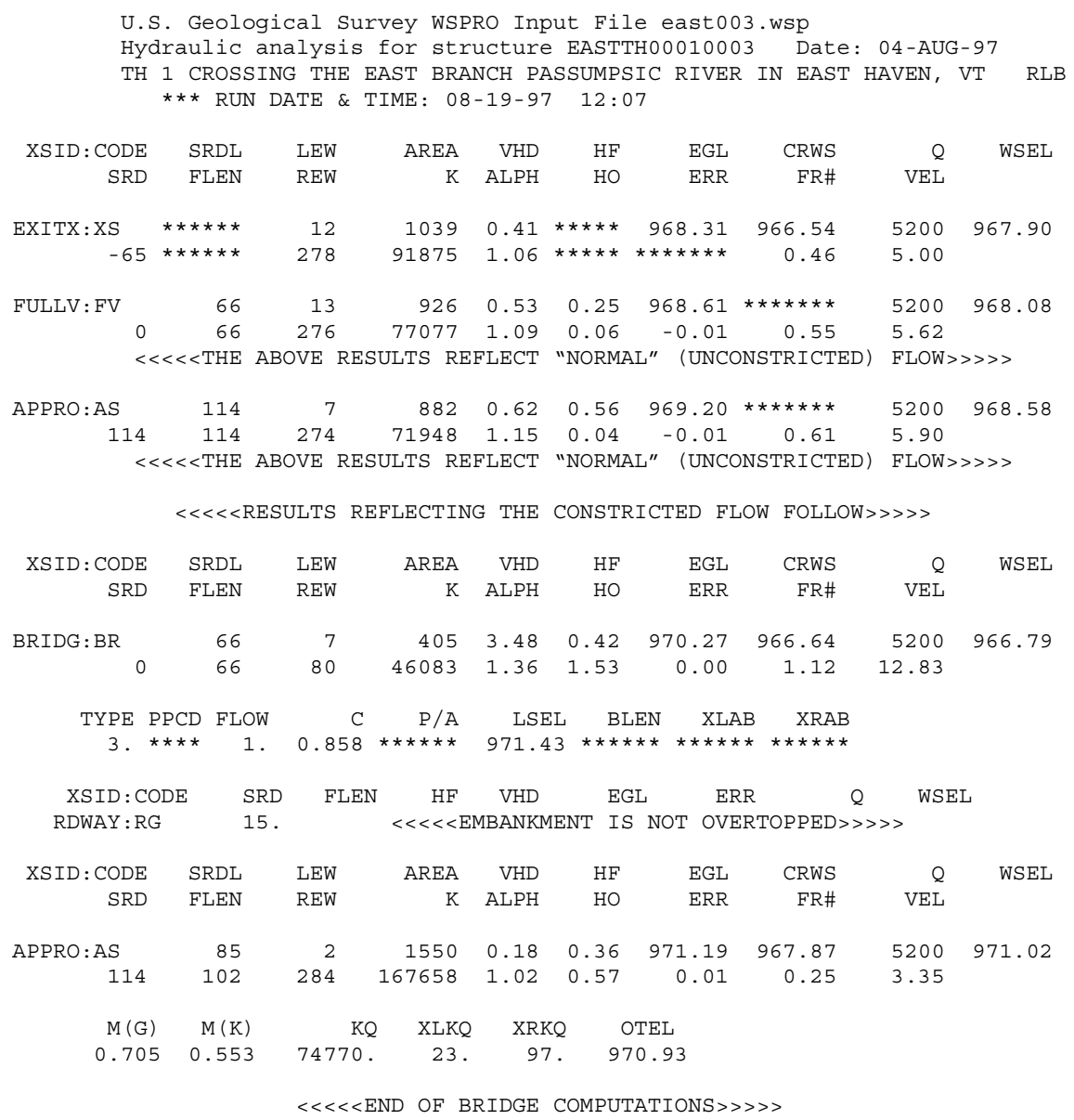

FIRST USER DEFINED TABLE.

\begin{tabular}{|c|c|c|c|c|c|c|c|c|}
\hline XSID : CODE & SRD & LEW & REW & $Q$ & $\mathrm{~K}$ & AREA & VEL & WSEL \\
\hline EXITX:XS & -66 & 12 . & 278. & 5200 . & 91875. & 1039 . & 5.00 & 967.90 \\
\hline FULLV : FV & 0 . & 13. & 276. & 5200. & 77077 . & 926. & 5.62 & 968.08 \\
\hline BRIDG : BR & 0 . & 7 . & 80 . & 5200. & 46083. & 405 & 12.83 & 966.79 \\
\hline RDWAY : RG & \multicolumn{3}{|c|}{ 15. $* * * * * * * * * * * * * *$} & \multicolumn{3}{|c|}{$0 . * * * * * * * * * * * * * * * * * *$} & \multicolumn{2}{|c|}{$1.00 * * * * * * * *$} \\
\hline APPRO : AS & 114 & 2 . & 284 . & 5200. & 167658. & 1550 & 3.35 & 971.02 \\
\hline XSID : CODE & XLKQ & XRKQ & & & & & & \\
\hline APPRO: AS & 23. & 97. & 7477 & & & & & \\
\hline
\end{tabular}

SECOND USER DEFINED TABLE.

\begin{tabular}{|c|c|c|c|c|c|c|c|c|c|}
\hline XSID : CODI & CRWS & FR\# & YMIN & YMAX & $\mathrm{HF}$ & HO & VHD & EGL & WSEL \\
\hline EXITX:XS & 966.54 & .46 & 958.42 & $982.00 *$ & $\pi x$ & *** & 0.41 & 968.31 & 967.90 \\
\hline ULLV : FV & 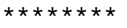 & .55 & 959.03 & 982.61 & 0.25 & 0.06 & 3 & 968.61 & 968.08 \\
\hline BRIDG : BR & 966.64 & .12 & 959.02 & 971.78 & 0.42 & 1.53 & 3.48 & 970.27 & 966.79 \\
\hline RDWAY : RG & 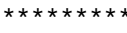 & $\star \star \star \star *$ & 972.94 & 012.86 * & 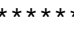 & $\star * *$ & * & $\star \star \star *$ & $\star * * * \star *$ \\
\hline PPRO:AS & 967.87 & 0.25 & 960.09 & 982.04 & 0.36 & 0.57 & 0.18 & 971.19 & 971.0 \\
\hline
\end{tabular}




\section{APPENDIX C:}

\section{BED-MATERIAL PARTICLE-SIZE DISTRIBUTION}




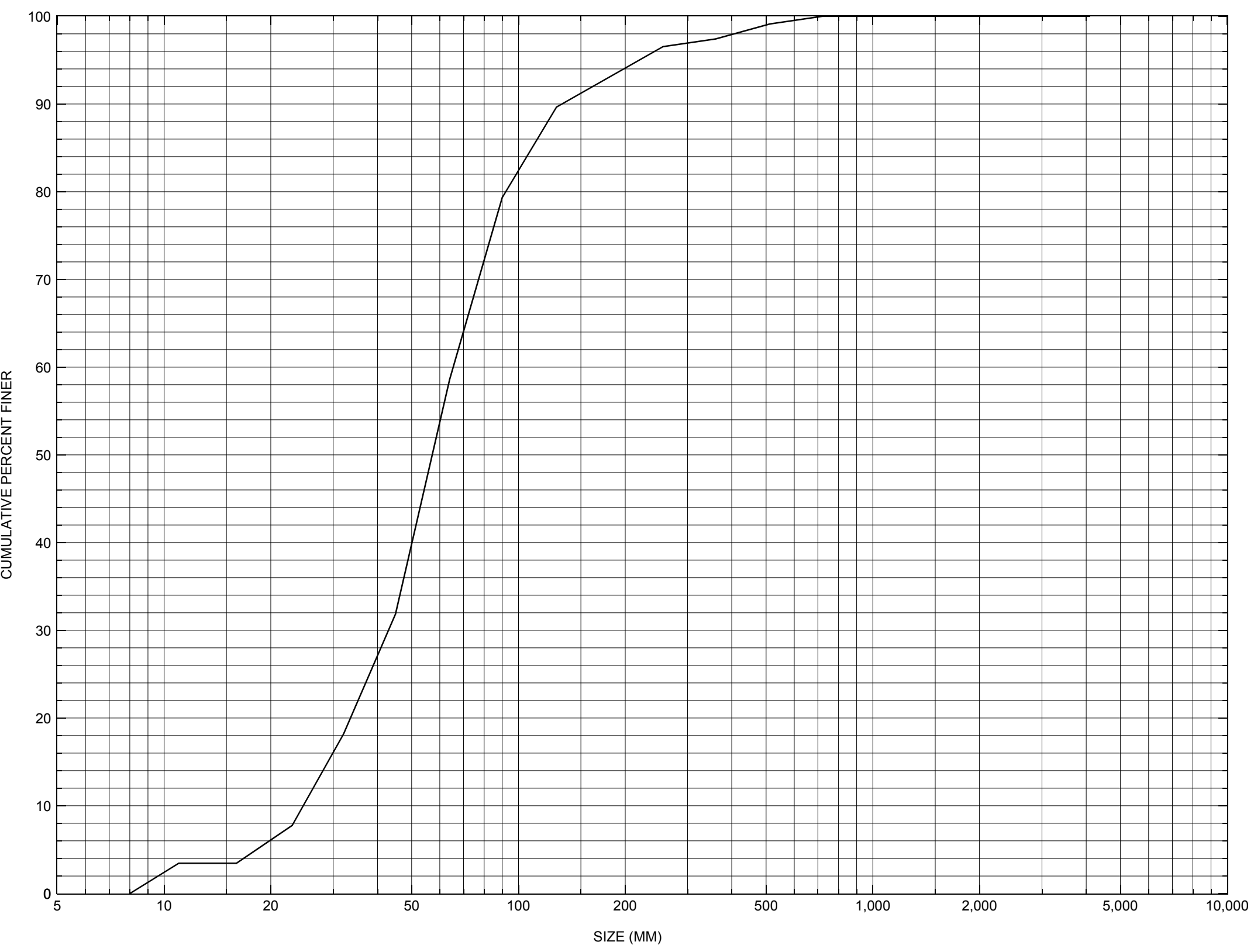

Appendix C. Bed material particle-size distribution for a pebble count in the channel approach of structure EASTTH00010003, in East Haven, Vermont. 


\section{APPENDIX D: \\ HISTORICAL DATA FORM}




\section{Structure Number EASTTH00010003}

\section{General Location Descriptive}

Data collected by (First Initial, Full last name) $\mathbf{E}$. BOEHMLER

Date $(M M / D D / Y Y) \_\mathbf{0 3} / \underline{17} / \underline{95}$

Highway District Number (I - 2; nn) $\mathbf{0 7}$

Town (FIPS place code; I - 4; nnnnn) $\mathbf{2 1 2 5 0}$

Waterway ( $($ - 6) EAST BRANCH PASSUMPSIC R.

Route Number TH001

Topographic Map West.Burke

Latitude (I - 16; nnnn.n) 44385
County (FIPS county code; I - 3; nnn)

Mile marker (I - 11; nnn.nnn) $\underline{\mathbf{0 0 0 0 0 0}}$

Road Name (I - 7): -

Vicinity (I - 9) 0.1 MI JCT TH 1 + VT 114

Hydrologic Unit Code: $\mathbf{0 1 0 8 0 1 0 2}$

Longitude (i - 17; nnnnn.n) 71535

\section{Select Federal Inventory Codes}

FHWA Structure Number (I - 8) $\mathbf{1 0 0 5 0 8 0 0 0 3 0 5 0 8 1}$

Maintenance responsibility $(I-21 ; n n) \quad \mathbf{0 3}$

Year built (I - 27; YYYY) 1961

Average daily traffic, ADT (I - 29; nnnnnn) 000750

Year of ADT (I - 30; YY) $\mathbf{9 4}$

Opening skew to Roadway $(I-34 ; n n) \quad \mathbf{0 0}$

Operational status $(I-41 ; X) \mathbf{R}$

Structure type (I - 43; nnn) $\mathbf{3 0 2}$

Approach span structure type $(I-44 ; n n n) \quad \mathbf{0 0 0}$

Number of spans (I - 45; nnn) $\underline{\mathbf{0 0 1}}$

Number of approach spans (I - 46; nnnn) $\mathbf{0 0 0 0}$

Comments:

The structural inspection report of 9/19/94 indicates the structure is a steel beam type bridge with a concrete deck and an asphalt roadway surface. The abutment walls are concrete and have minor fine cracks, a few leaks, and small spalls reported, mostly at the extreme upstream and downstream ends. There is boulder fill protection noted as placed on the embankment fill which slopes down in front of the abutment walls and around the ends of the walls. Some of the stone fill is noted as present along the upstream and downstream banks. Most of the flow appears to be along the protected embankment of the left abutment as the channel makes a gradual bend just upstream. 


\section{Bridge Hydrologic Data}

Is there hydrologic data available? $\mathbf{N}$ if No, type ctrl-n $h \quad$ VTAOT Drainage area $\left(\mathrm{mi}^{2}\right)$ : -

Terrain character: Hilly and forested

Stream character \& type: -

Streambed material:

Discharge Data (cfs):

$$
\begin{aligned}
& Q_{2.33}- \\
& Q_{50}-
\end{aligned}
$$

Record flood date (MM / DD / YY):

Estimated Discharge (cfs): Ice conditions (Heavy, Moderate, Light) : light

$$
\mathrm{Q}_{10} \frac{-}{\mathrm{Q}_{100}-}
$$$$
\mathrm{Q}_{25}
$$

Water surface elevation $(f t):-$

The stage increases to maximum highwater elevation (Rapidly, Not rapidly): Rapidly

The stream response is (Flashy, Not flashy):

Velocity at $Q$ $(\mathrm{ft} / \mathrm{s}):$

Describe any significant site conditions upstream or downstream that may influence the stream's stage: -

Watershed storage area (in percent):

The watershed storage area is: - _ (1-mainly at the headwaters; 2- uniformly distributed; 3-immediatly upstream oi the site)

Water Surface Elevation Estimates for Existing Structure:

\begin{tabular}{|l|l|l|l|l|l|}
\hline Peak discharge frequency & $Q_{2.33}$ & $Q_{10}$ & $Q_{25}$ & $Q_{50}$ & $Q_{100}$ \\
Water surface elevation (ft)) & - & - & - & - & - \\
Velocity $(\mathrm{ft} / \mathrm{sec})$ & - & - & - & - & - \\
\hline
\end{tabular}

Long term stream bed changes: -

Is the roadway overtopped below the $\mathrm{Q}_{100}$ ? (Yes, No, Unknown): $\mathbf{U}$ Frequency: Relief Elevation (ft): Discharge over roadway at $Q_{100}\left(f^{3} / \mathrm{sec}\right)$ :

Are there other structures nearby? (Yes, No, Unknown): $\mathbf{Y}$ Upstream distance (miles): Town: If No or Unknown, type ctrl-n os Highway No. :Structure No. :Year Built:

Clear span $(f t): \underline{\mathbf{2 7 . 0}}$ Clear Height $(f t):$ Full Waterway $\left(f^{2}\right): \mathbf{3 5 0 . 0}$ 
Downstream distance (miles): Town: Year Built:

Highway No. : Structure No. : Structure Type:

Clear span (ft): 10 Clear Height $(f t):$ Full Waterway $\left(t^{2}\right): \underline{\mathbf{4 2 0 . 0}}$

Comments:

Some hydrologic information that was printed on the plans is given above.

\section{USGS Watershed Data}

Watershed Hydrographic Data

Drainage area $(D A) \stackrel{\mathbf{5 0 . 3 8}}{\mathrm{mi}^{2}}$ Lake/pond/swamp area 0.41 $\mathrm{mi}^{2}$

Watershed storage (ST) $\%$

Bridge site elevation 975 $\mathrm{ft}$

Headwater elevation 3300 $\mathrm{ft}$

Main channel length 11.72 mi $10 \%$ channel length elevation $\mathbf{1 0 0 0}$ $\mathrm{ft} \quad 85 \%$ channel length elevation 1880 $\mathrm{ft}$

Main channel slope $(S)$ 100.15 $\mathrm{ft} / \mathrm{mi}$

Watershed Precipitation Data

Average site precipitation in Average headwater precipitation in

Maximum 2yr-24hr precipitation event $(124,2)$ in

Average seasonal snowfall (Sn) $\mathrm{ft}$ 


\section{Bridge Plan Data}

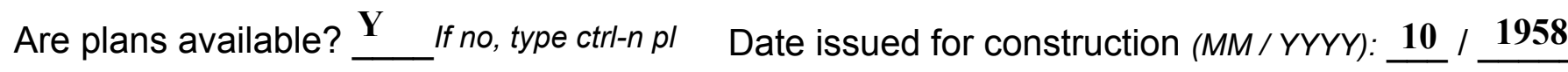
Project Number RAD 2(1)

Minimum channel bed elevation: $\mathbf{9 5 8 . 5}$

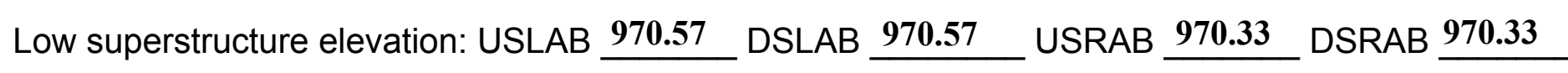
Benchmark location description:

$B M \# 3$ is a spike in the root of a $15 \mathrm{in}$. diameter elm tree located about 120 feet to intersection of side road from the left abutment at the centerline of the bridge's roadway, then about 1000 feet along the centerline of the side roadway to a cross road intersection, then diagonally into woods about 100 feet from the center of the intersection in a generally downstream and left direction, elevation 1010.76.

Reference Point (MSL, Arbitrary, Other): MSL Datum (NAD27, NAD83, Other): NGVD1929 Foundation Type: 2 (1-Spreadfooting; 2-Pile; 3- Gravity; 4-Unknown)

If 1: Footing Thickness _ _ Footing bottom elevation: 964.5

If 2: Pile Type: $\underline{\mathbf{2}}$ (1-Wood; 2-Steel or metal; 3-Concrete) Approximate pile driven length: $\underline{\mathbf{7 . 0}}$

If 3: Footing bottom elevation: -

Is boring information available? $\underline{\mathbf{Y}}$ If no, type ctrl-n bi Number of borings taken: $\underline{4}$

Foundation Material Type: 1 (1-regolith, 2-bedrock, 3-unknown)

Briefly describe material at foundation bottom elevation or around piles:

The highest elevation of boring refusal was approximately $957.0 \mathrm{ft}$. Hence, the piles are driven at least 7 feet from the bottom of the concrete base of the abutments. From the borings, the piles are driven into primarily coarse gravel.

Comments:

*The piles on the right abutment are proposed to be driven 25 feet and on the left, 10 feet. The piles are steel H-type piles. Other points provided with elevations on the plans are: 1) the point on the lowest of 3 step type concrete posts at the bottom of the rounded edge at the upstream right abutment corner of the post, elevation 978.78, and 2) The point at the same location as in (1) but on the downstream left abutment corner of the end post, elevation 979.14. 


\section{Cross-sectional Data}

Is cross-sectional data available? $\underline{\mathbf{Y}}$

If no, type ctrl-n xs

Source (FEMA, VTAOT, Other)? VTAOT

Comments: Upstream bridge channel cross section at stationing $4+90,10$ feet from the centerline of the roadway on the bridge deck. The channel baseline runs down the middle of the stream channel parallel to and 54 feet from the left abutment. Note: $b$ is the base of abutment footing.

\begin{tabular}{|l|l|l|l|l|l|l|l|l|l|l|l|}
\hline Station & $\mathbf{- 5 4 . 0}$ & $-\mathbf{5 1 . 5}$ & $\mathbf{- 3 8 . 8}$ & $\mathbf{- 3 6 . 0}$ & $\mathbf{+ 1 5}$ & $+\mathbf{1 7}$ & $\mathbf{3 0 . 5}$ & $\mathbf{3 3 . 0}$ & - & - & - \\
\hline Feature & LCL & - & LEW & BLB & BRB & REW & - & LCR & - & - & - \\
\hline $\begin{array}{l}\text { Low chord } \\
\text { elevation }\end{array}$ & $\mathbf{9 7 0 . 5}$ & - & - & - & - & - & - & $\mathbf{9 7 0 . 5}$ & - & - & - \\
\hline $\begin{array}{l}\text { Bed } \\
\text { elevation }\end{array}$ & - & $\mathbf{9 6 8 . 4}$ & $\mathbf{9 6 0}$ & $\mathbf{9 5 8 . 4}$ & $\mathbf{9 5 8 . 4}$ & $\mathbf{9 6 0}$ & $\mathbf{9 6 8 . 4}$ & - & - & - & - \\
\hline $\begin{array}{l}\text { Low chord- } \\
\text { bed }\end{array}$ & - & $\mathbf{b 9 6 4 . 4}$ & - & - & - & - & $\mathbf{b 9 6 4 . 5}$ & - & - & - & - \\
\hline Station & - & - & - & - & - & - & - & - & - & - & - \\
\hline Feature & - & - & - & - & - & - & - & - & - & - & - \\
\hline $\begin{array}{l}\text { Low chord } \\
\text { elevation }\end{array}$ & - & - & - & - & - & - & - & - & - & - & - \\
\hline $\begin{array}{l}\text { Bed } \\
\text { elevation }\end{array}$ & - & - & - & - & - & - & - & - & - & - & - \\
\hline $\begin{array}{l}\text { Low chord- } \\
\text { bed }\end{array}$ & - & - & - & - & - & - & - & - & - & - & - \\
\hline
\end{tabular}

Source (FEMA, VTAOT, Other)? VTAOT

Comments: Downstream bridge channel cross section at stationing $5+10,10$ feet from the centerline of the roadway on the bridge deck. $b$ : base of abutment footing.

\begin{tabular}{|l|l|l|l|l|l|l|l|l|l|l|l|}
\hline Station & -54 & -51.5 & -38.0 & $-\mathbf{3 6 . 0}$ & $+\mathbf{1 3}$ & $+\mathbf{1 5}$ & $\mathbf{2 8 . 4}$ & $\mathbf{3 1 . 0}$ & - & - & - \\
\hline Feature & LCL & - & LEW & BLB & BRB & REW & - & LCR & - & - & - \\
\hline $\begin{array}{l}\text { Low chord } \\
\text { elevation }\end{array}$ & $\mathbf{9 7 0 . 5}$ & - & - & - & - & - & - & $\mathbf{9 7 0 . 5}$ & - & - & - \\
\hline $\begin{array}{l}\text { Bed } \\
\text { elevation }\end{array}$ & - & $\mathbf{9 6 8 . 4}$ & $\mathbf{9 6 0}$ & $\mathbf{9 5 8 . 2}$ & $\mathbf{9 5 8 . 2}$ & $\mathbf{9 6 0}$ & $\mathbf{9 6 8 . 8}$ & - & - & - & - \\
\hline $\begin{array}{l}\text { Low chord- } \\
\text { bed }\end{array}$ & - & $\mathbf{6 9 6 4 . 5}$ & - & - & - & - & $\mathbf{b 9 6 4 . 5}$ & - & - & - & - \\
\hline Station & - & - & - & - & - & - & - & - & - & - & - \\
\hline Feature & - & - & - & - & - & - & - & - & - & - & - \\
\hline $\begin{array}{l}\text { Low chord } \\
\text { elevation }\end{array}$ & - & - & - & - & - & - & - & - & - & - & - \\
\hline $\begin{array}{l}\text { Bed } \\
\text { elevation }\end{array}$ & - & - & - & - & - & - & - & - & - & - & - \\
\hline $\begin{array}{l}\text { Low chord- } \\
\text { bed }\end{array}$ & - & - & - & - & - & - & - & - & - & - & - \\
\hline
\end{tabular}




\section{APPENDIX E: \\ LEVEL I DATA FORM}


U. S. Geological Survey

Bridge Field Data Collection and Processing Form

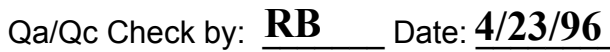

\section{Structure Number EASTTH00010003}

Computerized by: $\underline{\mathbf{R B}}$ Date: $4 / 23 / 96$

Reviewd by: $\quad$ RB Date: $\underline{\mathbf{8} / \mathbf{1 9} / 97}$

\section{A. General Location Descriptive}

1. Data collected by (First Initial, Full last name) E. BOEHMLER

Date $(M M / D D / Y Y) \underline{8}$

$14 / 1995$

2. Highway District Number $\mathbf{0 7}$

County ESSEX 009

Waterway $(l$ - 6) EAST BRANCH PASSUMPSIC R.

Route Number TH01

3. Descriptive comments:

Located about 0.1 miles east from TH01 intersection with VT114.
Mile marker 0000

Town EASTHAVEN 21250

Road Name -

Hydrologic Unit Code: $\mathbf{0 1 0 8 0 1 0 2}$

\section{B. Bridge Deck Observations}
4. Surface cover... LBUS 6
RBUS 4
LBDS 2
RBDS 4
Overall 4

(2b us,ds,lb,rb: 1- Urban; 2- Suburban; 3- Row crops; 4- Pasture; 5- Shrub- and brushland; 6- Forest; 7- Wetland)
5. Ambient water surface... US $\underline{2}$
UB 1
DS 2
(1- pool; 2- riffle)

6. Bridge structure type 1 (1- single span; 2- multiple span; 3- single arch; 4- multiple arch; 5-cylindrical culvert; 6- box culvert; or 7- other)
7. Bridge length $\mathbf{8 9}$ (feet)
Span length $\mathbf{8 7}$
(feet)
Bridge width 29

\section{Road approach to bridge:}
8. LB 0
RB 0
( 0 even, 1- lower, 2- higher)
9. $\mathrm{LB}$
RB 1
(1- Paved, 2- Not paved)

10. Embankment slope (run / rise in feet / foot):
US left
3.2:1
US right 0.8:1

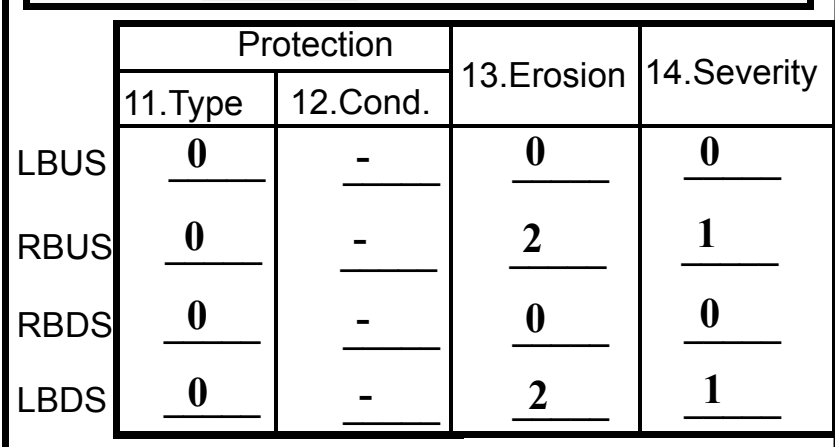

Bank protection types: 0 - none; 1- $<12$ inches;

2- < 36 inches; 3- < 48 inches;

4- $<60$ inches; 5- wall / artificial levee

Bank protection conditions: 1- good; 2- slumped;

3- eroded; 4- failed

Erosion: 0 - none; 1- channel erosion; 2-

road wash; 3- both; 4- other

Erosion Severity: 0 - none; 1- slight; 2- moderate; 3- severe

\section{Channel approach to bridge (BF):}

15. Angle of approach: $\mathbf{3 0}$

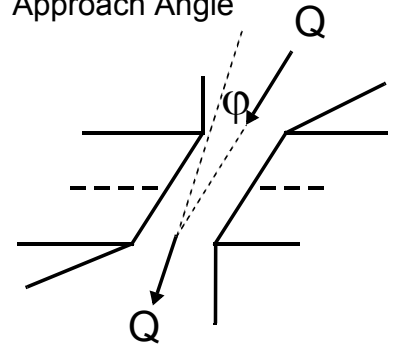

17. Channel impact zone 1 :

Where? LB $(L B, R B)$

Range? 40 feet US

Channel impact zone 2:

Where? LB $(L B, R B)$

Range? 15 feet DS

Impact Severity: 0- none to very slight; 1- Slight; 2- Moderate; 3- Severe
16. Bridge skew: $\mathbf{0}$ Bridge Skew Angle

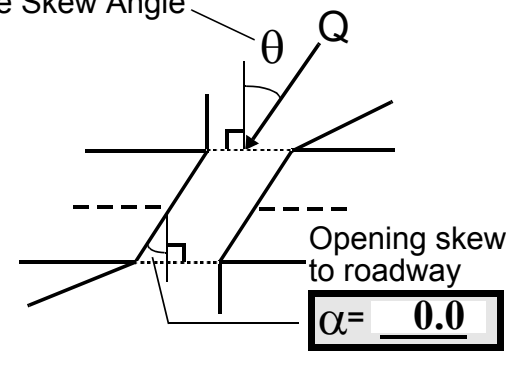

\section{Exist? $\mathbf{Y}(Y$ or $N)$}

Severity 1

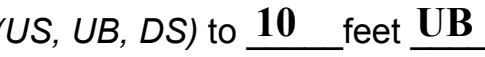

Exist? $\underline{\mathbf{Y}}(\mathrm{Y}$ or $N)$

Severity 2

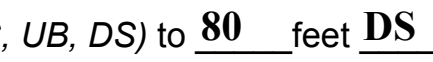


18. Bridge Type: $\mathbf{3}$

1a- Vertical abutments with wingwalls

1 b- Vertical abutments without wingwalls

2- Vertical abutments and wingwalls, sloping embankment Wingwalls parallel to abut. face

3- Spill through abutments

4- Sloping embankment, vertical wingwalls and abutments

Wingwall angle less than $90^{\circ}$.

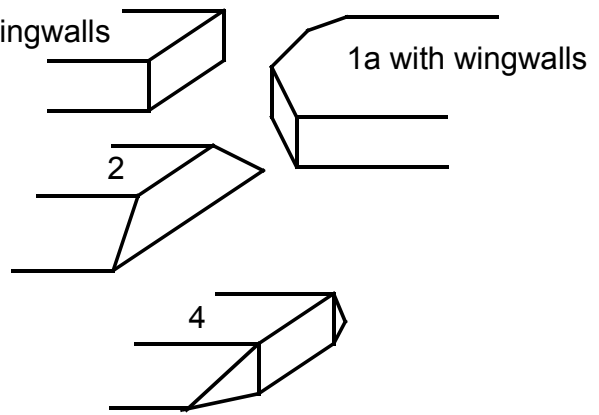

19. Bridge Deck Comments (surface cover variations, measured bridge and span lengths, bridge type variations, approach overflow width, etc.)

7. Values are from the VT AOT files. Measured bridge dimensions were the same except the bridge width which is 28.9 feet.

4. The surface cover on the US left bank is forest for a plot about 50 feet wide, then the cover is grass lawn with a few trailer homes and a side road. The DS left bank is suburban due to town public works garage, parking lot, gas tanks, etc. on the bank with grass surrounding the urban area and trees along the immediate bank. The US and DS right bank areas are back yard lawns for the homes on VT 114.

18. The abutments are concrete with stone fill placed in front acting as spill through embankments.

\section{Upstream Channel Assessment}

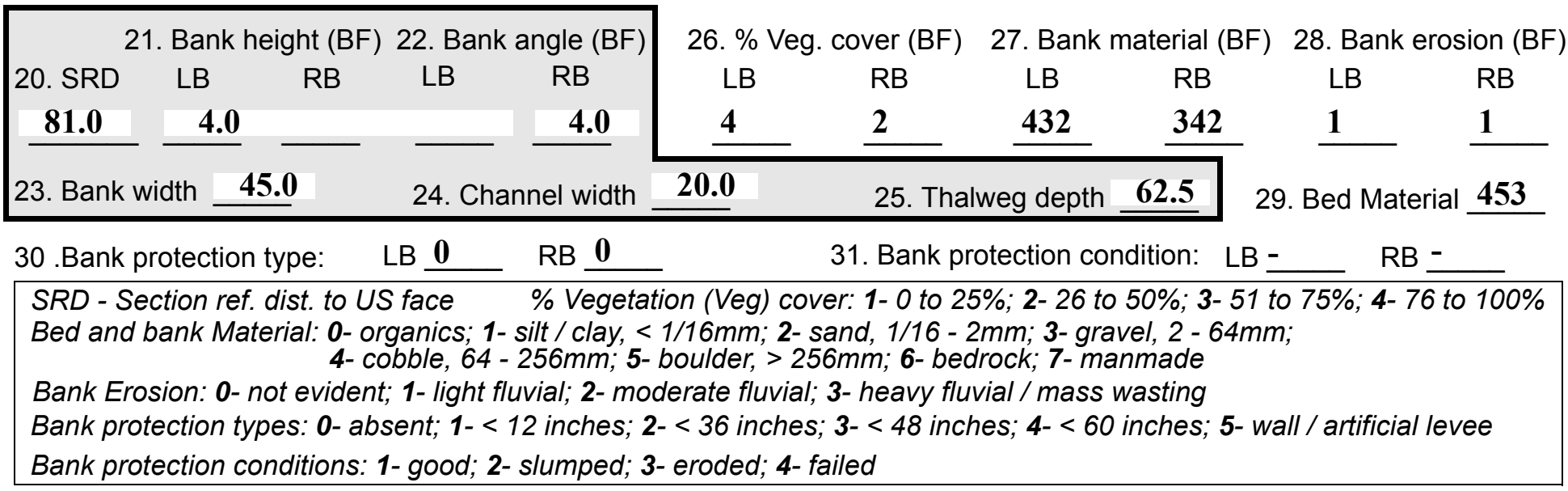

32. Comments (bank material variation, minor inflows, protection extent, etc.):

The thalweg US runs along the left bank side of the channel and is between 1 and 2 feet deep. No bank protection is evident. 
36. Point bar extent: $\underline{\mathbf{1 6 5}}$ feet $\underline{\mathrm{US}}$ (US, UB) to $\underline{\mathbf{1 8 5}}$ feet $\underline{\mathrm{US}}$ (US, UB, DS) positioned $\underline{\mathbf{7 0}} \%$ LB to $\underline{\mathbf{1 0 0}} \%$ RB

37. Material: $\mathbf{3 4 5}$

38. Point or side bar comments (Circle Point or Side; Note additional bars, material variation, status, etc.):

The point bar is partially submerged and is not vegetated. It is narrow in comparison with the channel width.

39. Is a cut-bank present? $\mathbf{Y}$ ( $Y$ or if $N$ type ctrl-n $c b)$

40. Where? LB (LB or RB)

41. Mid-bank distance: $\mathbf{6 0}$

42. Cut bank extent: $\underline{\mathbf{1 3 5}}$ feet $\underline{\mathrm{US}}$ (US, UB) to $\underline{\mathbf{2 0}}$ feet $\underline{\mathbf{U S}}$ (US, UB, DS)

43. Bank damage: 1

(1- eroded and/or creep; 2- slip failure; 3- block failure)

44. Cut bank comments (eg. additional cut banks, protection condition, etc.):

The bank cutting is in the form of small eroded pockets of bank material or scallops formed between tree trunks near the channel edge. It is minor.

\section{Is channel scour present? $\mathbf{N}$ ( $Y$ or if $N$ type ctrl-n cs)}

47. Scour dimensions: Length Width -

Depth : -

46. Mid-scour distance: -

48. Scour comments (eg. additional scour areas, local scouring process, etc.):

\section{NO CHANNEL SCOUR}

49. Are there major confluences? $\mathbf{Y}$

51. Confluence 1: Distance $\mathbf{5 0}$

Confluence 2: Distance -

52. Enters on $\underline{\mathbf{L B}}$ (LB or RB)

Enters on (LB or $R B)$

54. Confluence comments (eg. confluence name):

50. How many? 1

53. Type 1 (1- perennial; 2- ephemeral)

Type (1- perennial; 2- ephemeral)

$-$

55. Channel restraint (BF)? LB 2

\begin{tabular}{|cccc}
\hline \multicolumn{2}{|c}{ 56. Height (BF) } & \multicolumn{3}{c}{57 Angle (BF) } \\
LB & RB & LB & RB \\
$\mathbf{4 8 . 0}$ & & & $\mathbf{1 . 5}$ \\
\hline
\end{tabular}

58. Bank width (BF) (1- natural bank; 2- abutment; 3- artificial levee)

\section{Under Bridge Channel Assessment}

Bed and bank Material: 0- organics; 1- silt / clay, < 1/16mm; 2- sand, 1/16 - 2mm; 3- gravel, 2 - 64mm; 4- cobble, 64 - 256mm; 5- boulder, > 256mm; 6- bedrock; 7- manmade

\begin{tabular}{|c|c|c|c|}
\hline \multicolumn{2}{|c|}{ 61. Material (BF) } & \multicolumn{2}{|c|}{ 62. Erosion $(\mathrm{BF})$} \\
\hline LB & RB & LB & $\mathrm{RB}$ \\
\hline 2 & 7 & 7 & - \\
\hline
\end{tabular}

60. Thalweg depth $\lcm{90.0}$

63. Bed Material -

Bank Erosion: 0- not evident; 1- light fluvial; 2- moderate fluvial; 3- heavy fluvial / mass wasting

64. Comments (bank material variation, minor inflows, protection extent, etc.):

453

There is sone minor channel scour under the bridge with a length of 35 feet and a width of 15 feet. It is 0.5 feet deep and positioned $30 \%$ LB to $50 \%$ RB beginning at the US bridge face. 
65. Debris and Ice Is there debris accumulation?

(Yor $N)$ 66. Where? $\mathbf{N}$

(1- Upstream; 2- At bridge; 3- Both)

67. Debris Potential ( 1- Low; 2- Moderate; 3- High)

68. Capture Efficiency 2

(1-Low; 2- Moderate; 3- High)

69. Is there evidence of ice build-up? 1 (Y or $N)$

Ice Blockage Potential $\underline{\mathbf{Y}}$

(1- Low; 2- Moderate; 3- High)

70. Debris and Ice Comments:

1

The debris potential is moderate because of the abundance of trees on the banks and the sinuosity of the stream. The bridge, however, is wide and the stream passes straight beneath it and has a high gradient so debris and ice are unlikely to build up. On the left bank just DS of the bridge there are large scars in the bark of the trees about 6 feet above the current water level showing evidence of ice build up or impact.

\begin{tabular}{|l|c|c|c|c|c|c|c|c|}
\hline Abutments & $\begin{array}{c}\text { 71. Attack } \\
\angle \mathrm{BF})\end{array}$ & $\begin{array}{c}72 . \text { Slope } \\
(\mathrm{Qmax})\end{array}$ & $\begin{array}{l}\text { 73. Toe } \\
\text { loc. (BF) }\end{array}$ & $\begin{array}{c}\text { 74. Scour } \\
\text { Condition }\end{array}$ & $\begin{array}{c}\text { 75. Scour } \\
\text { depth }\end{array}$ & $\begin{array}{c}\text { 76. Exposure } \\
\text { depth }\end{array}$ & 77. Material & 78. Length \\
\hline LABUT & & $\mathbf{5}$ & $\mathbf{3 5}$ & $\mathbf{2}$ & $\mathbf{0}$ & $\mathbf{0}$ & $\mathbf{0}$ & $\mathbf{9 0 . 0}$ \\
\hline RABUT & $\mathbf{1}$ & - & $\mathbf{2 5}$ & & & $\mathbf{2}$ & $\mathbf{0}$ & $\mathbf{8 4 . 5}$ \\
\hline
\end{tabular}

Pushed: $L B$ or RB

Toe Location (Loc.): 0- even, 1- set back, 2- protrudes

Scour cond.: 0- not evident; 1- evident (comment); 2- footing exposed; 3-undermined footing; 4- piling exposed; 5- settled; 6- failed

Materials: 1- Concrete; 2- Stone masonry or drywall; 3- steel or metal; 4- wood

79. Abutment comments (eg. undermined penetration, unusual scour processes, debris, etc.):

0

0

1

Both abutments are vertical concrete protected with a sloping embankment of type 4 stone fill blocks carefully placed on the finer fill beneath.

80. Wingwalls:

$\begin{array}{llll}\text { Exist? Material? } & \text { Scour } & \text { Scour Exposure } & \text { Angle? Length? } \\ & \text { Condition? depth? } & \text { depth? }\end{array}$

USLWW:

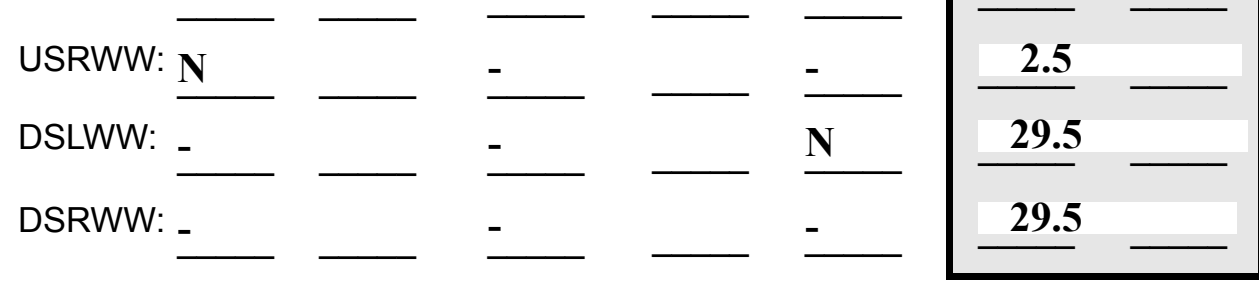

Wingwall materials: 1- Concrete; 2- Stone masonry or drywall; 3- steel or metal; 4- wood

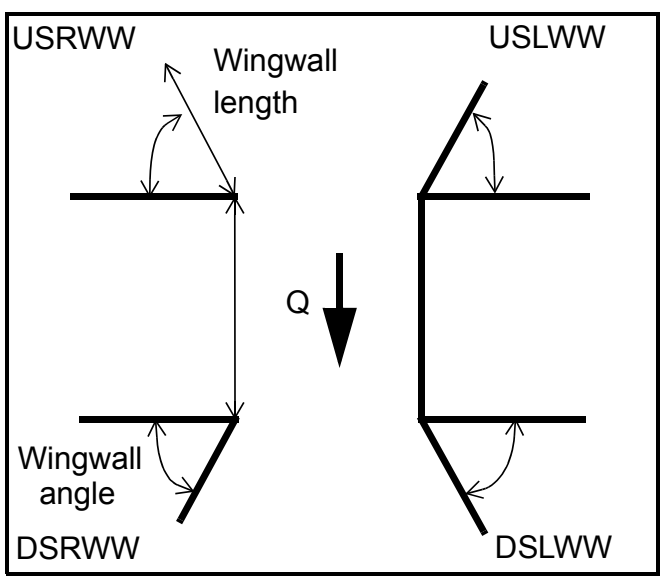

82. Bank / Bridge Protection:

\begin{tabular}{|l|l|l|l|l|l|l|l|c|}
\hline Location & USLWW & USRWW & LABUT & RABUT & LB & RB & DSLWW & DSRWW \\
\hline Type & - & - & N & - & - & - & $\mathbf{1}$ & $\mathbf{1}$ \\
\hline Condition & N & - & - & - & - & - & $\mathbf{1}$ & $\mathbf{1}$ \\
\hline Extent & - & - & - & - & - & $\mathbf{4}$ & $\mathbf{4}$ & - \\
\hline
\end{tabular}

Bank / Bridge protection types: 0- absent; 1- < 12 inches; 2- < 36 inches; 3- < 48 inches; 4- < 60 inches; 
83. Wingwall and protection comments (eg. undermined penetration, unusual scour processes, etc.):

-
-
-
-
-
-
-
-
-

\section{Piers:}

84. Are there piers? Th (Y or if $N$ type ctrl-n pr)

\begin{tabular}{|l|l|l|l|l|l|l|l|}
\hline \multirow{2}{*}{$\begin{array}{l}85 . \\
\text { Pier no. }\end{array}$} & \multicolumn{3}{|c|}{ width (w) feet } & \multicolumn{3}{c|}{ elevation (e) feet } \\
\cline { 2 - 9 } & w1 & w2 & w3 & e@w1 & e@w2 & e@w3 \\
\hline Pier 1 & - & - & - & - & - & - \\
\hline Pier 2 & - & - & - & - & - & - \\
\hline Pier 3 & - & - & - & - & - & - \\
\hline Pier 4 & - & - & - & - & - & - \\
\hline
\end{tabular}

\begin{tabular}{|l|l|l|l|l|}
\hline Level 1 Pier Descr. & \multicolumn{1}{|c|}{1} & \multicolumn{1}{|c|}{2} & 3 & \multicolumn{1}{|l|}{} \\
\hline 86. Location (BF) & ere are & ments & & - \\
\hline 87. Type & no & acts & & - \\
\hline 88. Material & wing & as & & - \\
\hline 89. Shape & walls & spill & & - \\
\hline 90. Inclined? & thro & & - \\
\hline 91. Attack $\angle$ (BF) & The & ugh & & - \\
\hline 92. Pushed & pro- & emb & & - \\
\hline 93. Length (feet) & - & - & - & - \\
\hline 94. \# of piles & tec- & ank- & N & - \\
\hline 95. Cross-members & tion & ment & - & - \\
\hline 96. Scour Condition & on & s. & - & - \\
\hline 97. Scour depth & the & & - & - \\
\hline 98. Exposure depth & abut & & - & - \\
\hline
\end{tabular}

LFP, LTB, LB, MCL, MCM, MCR, RB, RTB, RFP

1- Solid pier, 2- column, 3- bent

1-Wood; 2- concrete; 3- metal; 4- stone

1- Round; 2- Square; 3- Pointed

Y-yes; $N-$ no

$L B$ or $R B$

0- none; 1- laterals; 2- diagonals; 3- both

0- not evident; 1- evident (comment);

2- footing exposed; 3- piling exposed;

4- undermined footing; 5- settled; 6- failed 
99. Pier comments (eg. undermined penetration, protection and protection extent, unusual scour processes, etc.):

-
-
-
-
-
-
-
-
-
-

100.

\section{E. Downstream Channel Assessment}

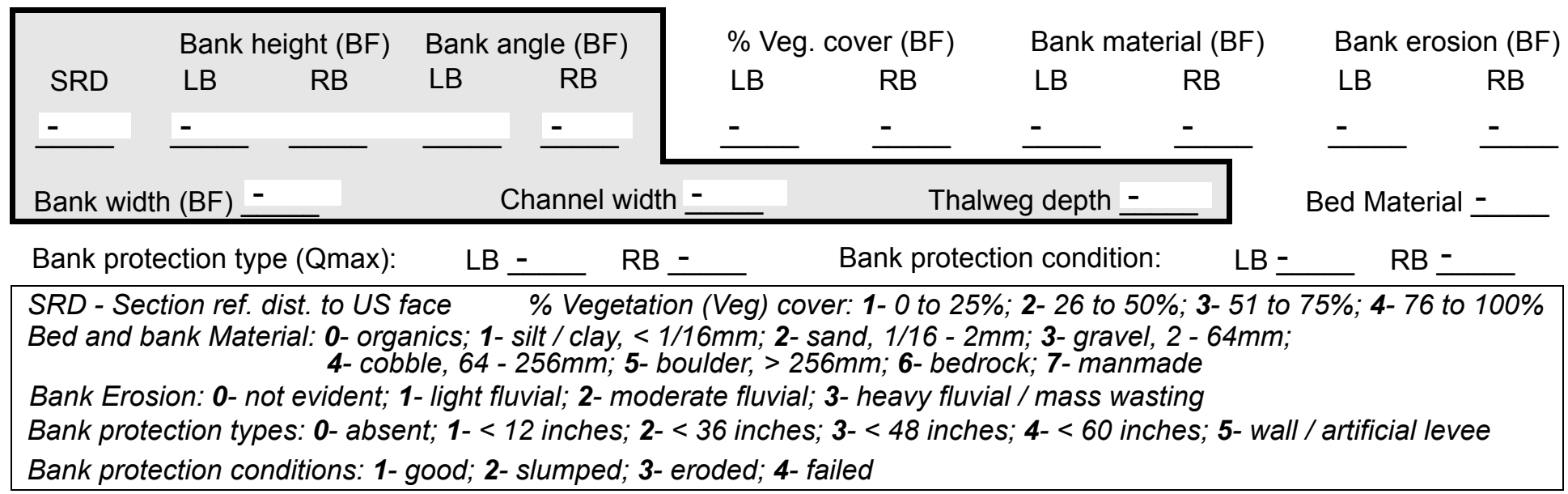

Comments (eg. bank material variation, minor inflows, protection extent, etc.):

-
-
-
-
-
-
-
-
-
-

\section{NO PIERS}

101. Is a drop structure present? ( $Y$ or $N$, if $N$ type ctrl-n ds) 102. Distance: _ feet (1- steel sheet pile; 2- wood pile; 3- concrete; 4- other)

105. Drop structure comments (eg. downstream scour depth): 
106. Point/Side bar present? $\underline{\mathbf{3 2}}$ (Y or N. if N type ctrl-n pb)Mid-bar distance: $\mathbf{4}$

Mid-bar width: 324

Point bar extent: 1 feet 1

(US, UB, DS) to $\underline{453}$ feet $\underline{2}$ (US, UB, DS) positioned $\mathbf{0}$ $\%$ LB to $\underline{2} \%$ RB

Material:

Point or side bar comments (Circle Point or Side; note additional bars, material variation, status, etc.):

The left bank protection extends from the DS bridge face to 125 feet DS. The protection forms a nearly flat shelf at the edge of the left bank. Further up on the bank, however, there is some bank cutting. Beyond the 125 feet DS the reach is mainly straight and there is some slight bank cutting along the toes of each bank to greater than 200 feet DS.

Is a cut-bank present? (Y or if $N$ type ctrl-n cb) Where? (LB or $R B)$

Mid-bank distance:

Cut bank extent: feet (US, UB, DS) to feet (US, UB, DS)

Bank damage: (1- eroded and/or creep; 2- slip failure; 3- block failure)

Cut bank comments (eg. additional cut banks, protection condition, etc.):

$\mathbf{N}$

Is channel scour present? _-_ (Y or if N type ctrl-n cs) Mid-scour distance: NO

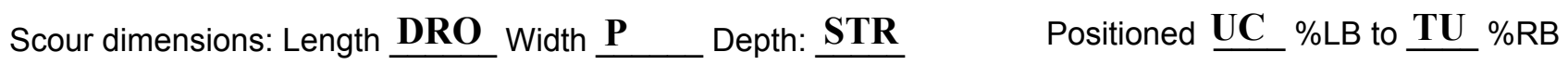
Scour comments (eg. additional scour areas, local scouring process, etc.):

RE

Are there major confluences? ( $Y$ or if $N$ type ctrl-n $m c)$

How many?

Confluence 1: Distance $\underline{\mathbf{Y}}$ Enters on 100 ( $L B$ or $R B)$

Type 11 (1- perennial; 2- ephemeral)

Confluence 2: Distance $\mathbf{3 0}$ Enters on DS (LB or RB)

Type $\underline{125}$ (1-perennial; 2-ephemeral)

Confluence comments (eg. confluence name):

DS

85

\section{F. Geomorphic Channel Assessment}

107. Stage of reach evolution $\mathbf{1 0 0}$

1- Constructed

2- Stable

3- Aggraded

4- Degraded

5- Laterally unstable

6- Vertically and laterally unstable 
108. Evolution comments (Channel evolution not considering bridge effects; See HEC-20, Figure 1 for geomorphic descriptors):

324

This point bar is narrow and not vegetated.

Y

LB

50

20

DS

75

DS

1 


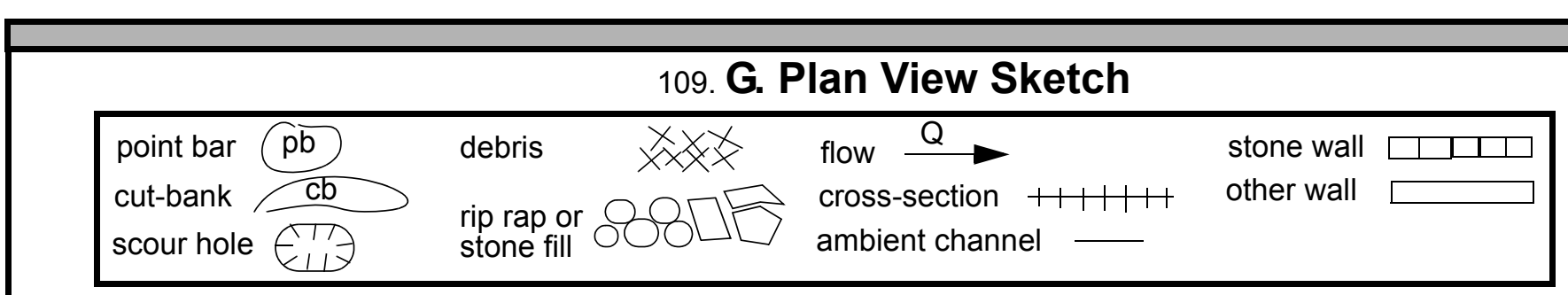


APPENDIX F:

SCOUR COMPUTATIONS 


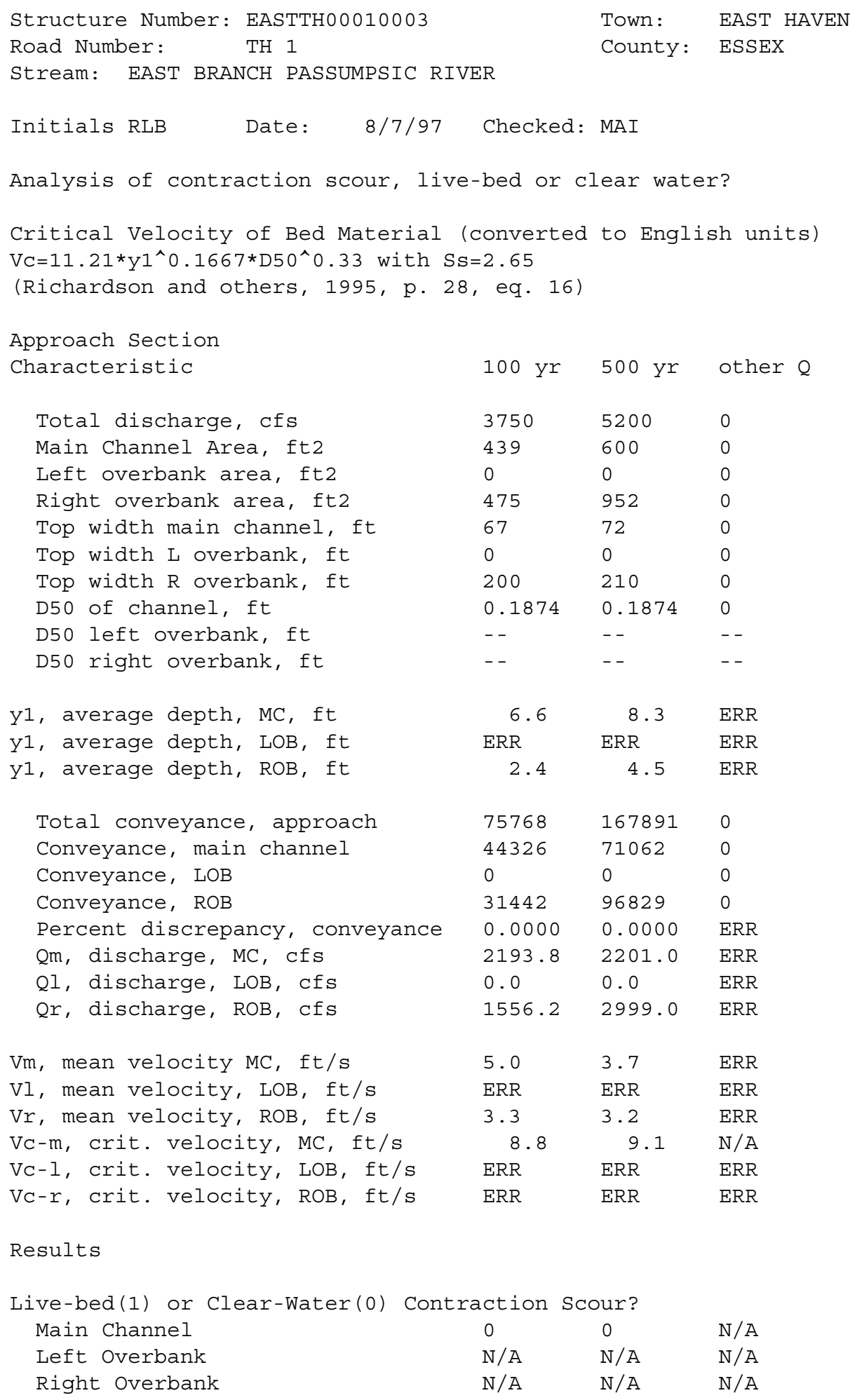


Clear water Contraction Scour in MAIN CHANNEL

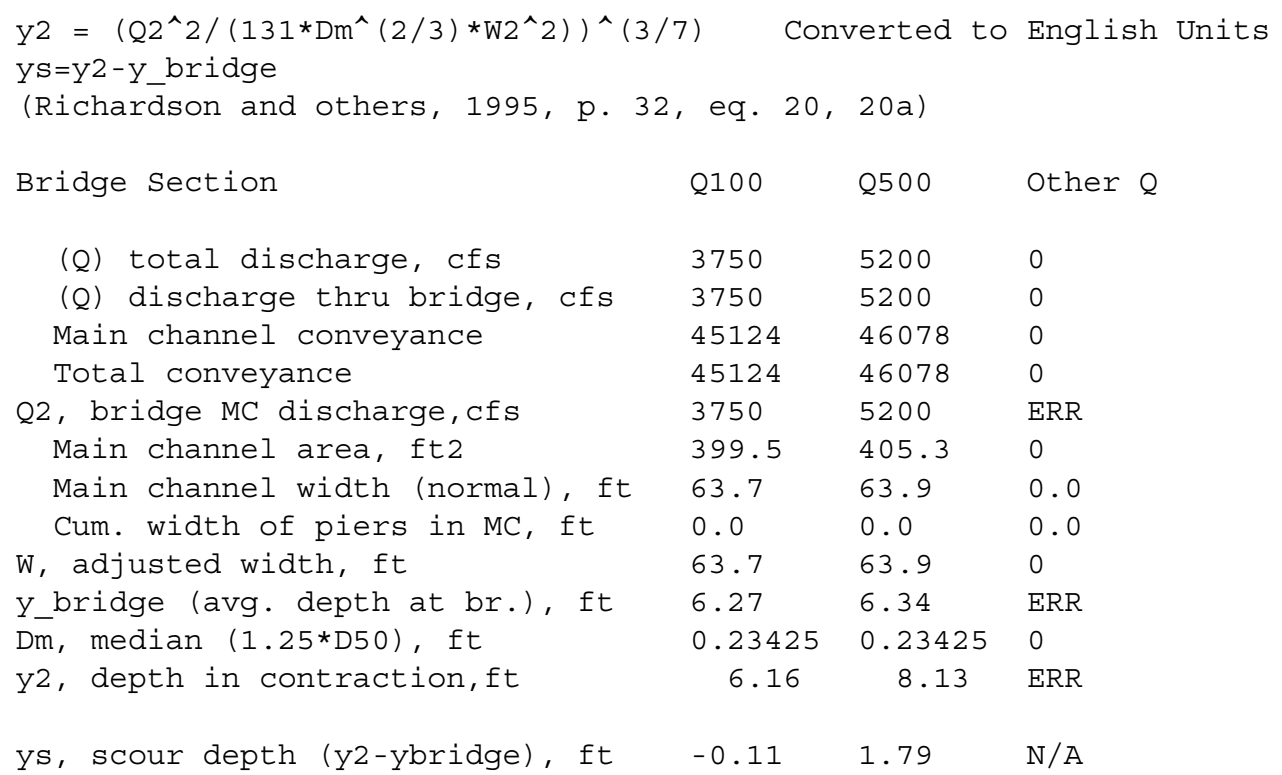

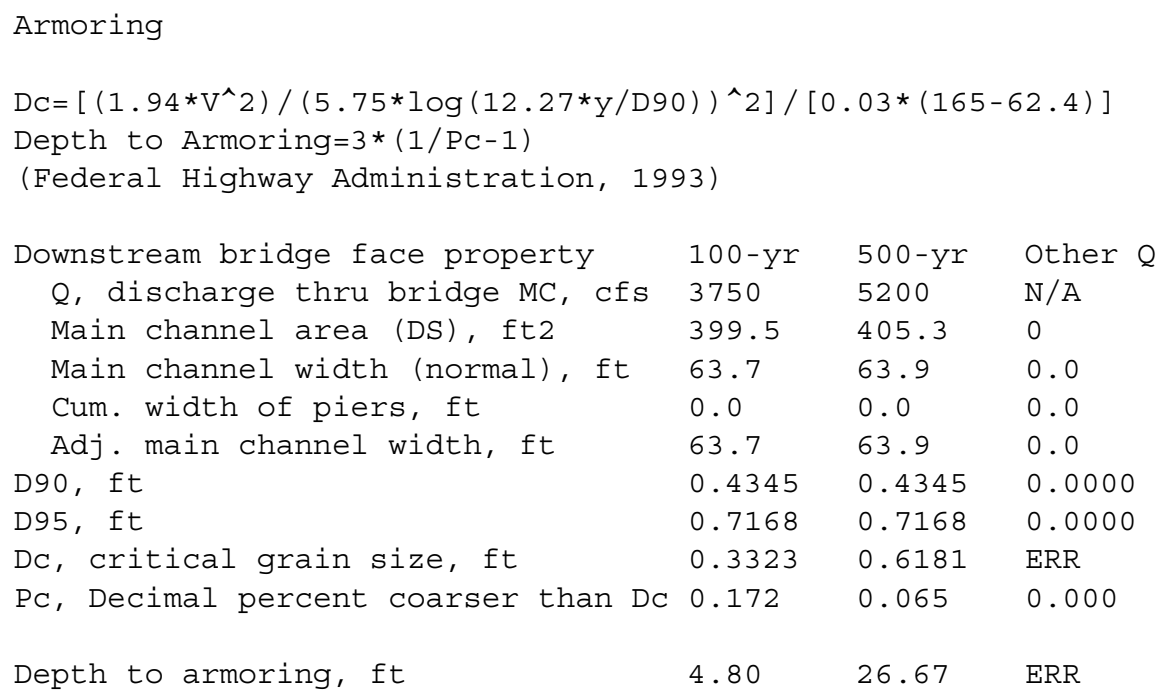


Abutment Scour

Froehlich's Abutment Scour

$\mathrm{Ys} / \mathrm{Y} 1=2.27 * \mathrm{~K} 1 * \mathrm{~K} 2 *\left(\mathrm{a}^{\prime} / \mathrm{Y} 1\right) \wedge 0.43 * \mathrm{Fr} 1 \wedge 0.61+1$

(Richardson and others, 1995, p. 48, eq. 28)

\begin{tabular}{|c|c|c|c|c|c|c|}
\hline \multirow[b]{2}{*}{ Characteristic } & \multicolumn{2}{|c|}{ Left Abutment } & \multicolumn{4}{|c|}{ Right Abutment } \\
\hline & \multicolumn{3}{|c|}{100 yr Q 500 yr Q Other } & \multicolumn{3}{|c|}{$100 \mathrm{yr} Q 500 \mathrm{yr} Q$ Other Q } \\
\hline (Qt), total discharge, cfs & 3750 & 5200 & 0 & 3750 & 5200 & 0 \\
\hline a', abut.length blocking flow, ft & 3.7 & 8.5 & 0 & 200.2 & 209.7 & 0 \\
\hline Ae, area of blocked flow ft 2 & 15.07 & 44.98 & 0 & 480.07 & 954.6 & 0 \\
\hline Qe, discharge blocked abut., cfs & 49.91 & 111.06 & 0 & 1572.12 & 2999.6 & 0 \\
\hline \multicolumn{7}{|c|}{ (If using Qtotal_overbank to obtain Ve, leave Qe blank and enter Ve and Fr manually) } \\
\hline Ve, $(\mathrm{Qe} / \mathrm{Ae}), \mathrm{ft} / \mathrm{s}$ & 3.31 & 2.47 & ERR & 3.27 & 3.14 & $\mathrm{ERR}$ \\
\hline ya, depth of $f / p$ flow, ft & 4.07 & 5.29 & ERR & 2.40 & 4.55 & ERR \\
\hline \multicolumn{7}{|c|}{--Coeff., K1, for abut. type (1.0, verti.; 0.82, verti. w/ wingwall; 0.55, spillthru) } \\
\hline K1 & 0.55 & 0.55 & 0 & 0.55 & 0.55 & 0 \\
\hline --Angle (theta) of embankment $(<90$ & if abut & points & $>90$ & abut. po & ats US) & \\
\hline theta & 90 & 90 & 0 & 90 & 90 & 0 \\
\hline K2 & 1.00 & 1.00 & 0.00 & 1.00 & 1.00 & 0.00 \\
\hline Fr, froude number $f / p$ flow & 0.289 & 0.189 & ERR & 0.373 & 0.260 & ERR \\
\hline ys, scour depth, ft & 6.36 & 8.22 & $\mathrm{~N} / \mathrm{A}$ & 13.39 & 17.51 & $\mathrm{~N} / \mathrm{A}$ \\
\hline \multicolumn{7}{|l|}{ HIRE equation (a'/ya > 25) } \\
\hline \multicolumn{7}{|c|}{$\begin{array}{l}\mathrm{ys}=4 * \mathrm{Fr}^{\wedge} 0.33 * \mathrm{Y} 1 * \mathrm{~K} / 0.55 \\
(\mathrm{Richardson} \text { and others, 1995, p. 49, eq. 29) }\end{array}$} \\
\hline$a^{\prime}$ (abut length blocked, ft) & 3.7 & 8.5 & 0 & 200.2 & 209.7 & 0 \\
\hline y1 (depth f/p flow, ft) & 4.07 & 5.29 & ERR & 2.40 & 4.55 & ERR \\
\hline$a^{\prime} / y^{1}$ & 0.91 & 1.61 & ERR & 83.49 & 46.07 & ERR \\
\hline Skew correction (p. 49, fig. 16) & 1.00 & 1.00 & 1.00 & 1.00 & 1.00 & 1.00 \\
\hline Froude no. f/p flow & 0.29 & 0.19 & $\mathrm{~N} / \mathrm{A}$ & 0.37 & 0.26 & $\mathrm{~N} / \mathrm{A}$ \\
\hline \multirow{3}{*}{$\begin{array}{l}\text { Ys w/ corr. factor K1/0.55 } \\
\text { vertical } \\
\text { vertical w/ ww's } \\
\text { spill-through }\end{array}$} & ERR & ERR & ERR & 12.59 & 21.21 & ERR \\
\hline & ERR & $E R R$ & $\mathrm{ERR}$ & 10.32 & 17.39 & $\mathrm{ERR}$ \\
\hline & ERR & ERR & ERR & 6.93 & 11.67 & $E R R$ \\
\hline
\end{tabular}




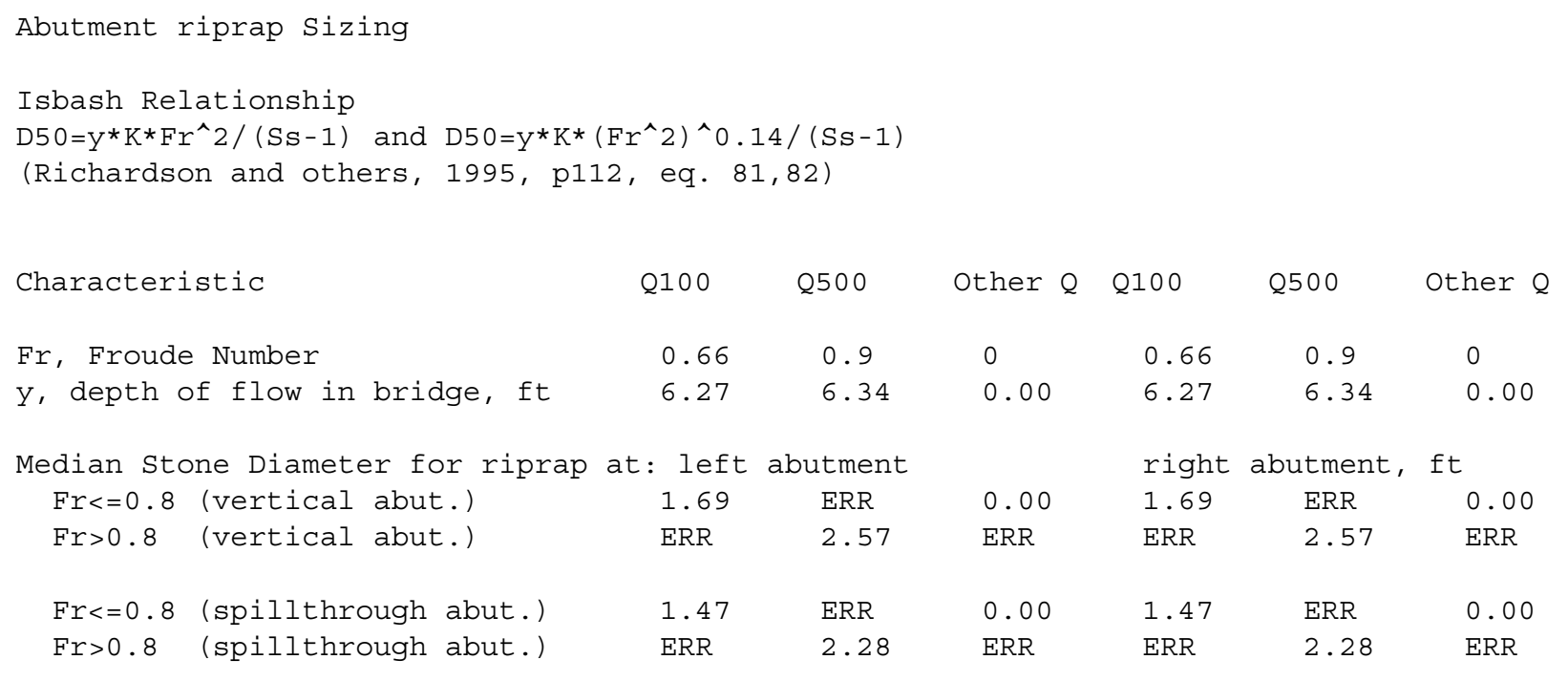

